\title{
Nocturnal fish movement and trophic flow across habitat boundaries in a coral reef ecosystem (SW Puerto Rico)
}

\author{
Randall D. Clark ${ }^{1 *}$, Simon Pittman ${ }^{1}$, Chris Caldow ${ }^{1}$, John Christensen ${ }^{1}$, \\ Bryant Roque ${ }^{2}$, Richard S. Appeldoorn ${ }^{2}$, And Mark E. Monaco ${ }^{1}$ \\ ${ }^{1}$ National Oceanic and Atmospheric Administration, Biogeography Branch, 1305 East-West Highway, \\ Silver Spring, MD 20910 USA \\ ${ }^{2}$ Department of Marine Sciences, University of Puerto Rico, Mayaguez, Puerto Rico 00681-9013 USA \\ *Email: randy.clark@noaa.gov
}

\begin{abstract}
Aвstract.-Few studies have quantified the extent of nocturnal cross-habitat movements for fish, or the influence of habitat adjacencies on nutrient flows and trophodynamics. To investigate the patterns of nocturnal cross-boundary movements of fish and quantify trophic connectivity, fish were sampled at night with gillnets set along the boundaries between dominant habitat types (coral reef/seagrass and mangrove/ seagrass) in southwestern Puerto Rico. Fish movement across adjacent boundary patches were equivalent at both coral reefs and mangroves. Prey biomass transfer was greater from seagrass to coral reefs $(0.016 \mathrm{~kg} / \mathrm{km})$ and from mangroves to seagrass $(0.006 \mathrm{~kg} / \mathrm{km})$ but not statistically significant, indicating a balance of flow between adjacent habitats. Pelagic species (jacks, sharks, rays) accounted for $37 \%$ of prey biomass transport at coral reef/seagrass and $46 \%$ at mangrove/seagrass while grunts and snappers accounted for $7 \%$ and $15 \%$, respectively. This study indicated that coral reefs and mangroves serve as a feeding area for a wide range of multi-habitat fish species. Crabs were the most frequent prey item in fish leaving coral reefs while molluscs were observed slightly more frequently than crabs in fish entering coral reefs. For most prey types, biomass exported from mangroves was greater than biomass imported. The information on direction of fish movement together with analysis of prey data provided strong evidence of ecological linkages between distinct adjacent habitat types and highlighted the need for greater inclusion of a mosaic of multiple habitats when attempting to understand ecosystem function including the spatial transfer of energy across the seascape.
\end{abstract}

KEYWORDS.-connectivity, habitat boundaries, coral reef ecosystems, mangroves, fish prey, nocturnal fish movement, seascape

\section{INTRODUCTION}

Many fish species in tropical coral reef ecosystems connect multiple habitats through regular nocturnal migrations into neighboring habitats, with some species using several distinct resources across a compositionally complex mosaic of habitats (Parrish 1989; Kramer and Chapman 1999; Nagelkerken et al. 2000; Cocheret de la Moriniere 2002; Dorenbosch et al. 2005; Unsworth et al. 2008). For instance, Meyer et al. (1983) reported at least 15 fish families that leave coral reefs to forage in neighboring areas. Haemulidae (grunts) and Lutjanidae (snappers) in the Caribbean have frequently been observed to undertake sun-synchronous migrations by leaving their daytime shelter on coral reefs and mangroves at dusk to migrate to adjacent seagrass and sand beds to forage at night before returning to the more structured habitat types by dawn (Ogden and Ehrlich 1977, Helfman et al. 1982; Rooker and Dennis 1991; Nagelkerken et al. 2000; Monaco et al. 2009). Seagrass beds provide a high abundance of food and suitable refuge in low light conditions, thus functioning as a complementary or supplementary resource for many multi-habitat species (Pittman et al. 2004, Pittman et al. 2007). This pattern of day-night resource use has likely evolved to maximize growth while minimizing mortality through predation (Dahlgren and Eggleston 2000, Grol et al. 2008). Community studies have shown that nocturnal excursions can result in pronounced diel shifts in fish assemblage composition across interconnected coral reef ecosystems (Kopp et al. 
2007; Unsworth et al. 2007). Since most studies of fish movement occur during daylight hours, little is known about the identity and abundance of nocturnal trans-boundary movements. Earlier studies of migrating resident species (e.g. grunts, snappers) suggest net trophic flow of prey biomass to be greater coming back to the resting habitat type (Ogden and Ehrlich 1977; Ogden and Zieman 1977; McFarland et al. 1979).

Fish migrations have long been considered to be important conduits of organic and inorganic material to and from coral reefs, mangroves and surrounding areas (Birkeland 1985; Meyer and Schultz 1985; Parrish 1989; Sheaves 2005), yet since the publication of Randall's (1967) dietary survey of 212 Caribbean fish relatively little quantitative information is available on multi-species foraging and diets. Even fewer studies have focused on the exchanges of organisms and dietary material across boundaries between neighboring habitats. This is an important knowledge gap since fishes have been shown to be a significant source of organic carbon and other nutrients in tropical marine ecosystems (Bray et al. 1981; Ogden and Gladfelter 1983). For example, early experiments on the effects of excretion and defecation from migrating schools of fish over coral reefs indicated significant inputs of ammonium and phosphorous that may enhance the growth of macroalgae (Meyer et al. 1983; Meyer and Schultz 1985). In addition, foraging fish have been identified as a key redistributer of sediment particles in coral reef ecosystems (Alheit 1981) and the transport of nutrients and transfer of energy away from mangroves by mobile animals can have important consequences for recycling in mangroves (Sheaves and Molony 2000; Sheaves 2005).

Parrish (1989) and Polis et al. (1997) argue that trophic interactions that connect discrete habitat types can exert a major influence on the local abundance and distribution of organisms through both "bottomup" processes as a result of cross-habitat transport of materials and nutrients and top-down processes as a result of predation. As we progress toward understanding seascape structure and the dynamics and energy pathways across the seascape, there is an urgent need for quantitative information capable of identifying pathways of energy flow and determining the influence of habitat boundaries and habitat adjacencies on these processes. In this way, we begin to link ecological patterns with dynamic ecological processes across structural mosaics of habitat in coral reef ecosystems. This fundamental ecological information can be applied to help understand factors including human modifications that may enhance or limit energy flow across coral reef ecosystems and may also help determine the optimal design of Marine Protected Areas (MPAs) and help refine designations of Essential Fish Habitat (EFH) (Polunin and Roberts 1993; Murray et al. 1999).

This paper examines inter-habitat trophic connectivity across the seascape of $\mathrm{La}$ Parguera, SW Puerto Rico by examining the flow of fish biomass and their associated prey. Numerous adult and sub-adult fish species were captured during their nocturnal excursions across: (A) the boundary of coral reefs and seagrasses $(\mathrm{C} r-\mathrm{Sg})$, and (B) the boundary of mangroves and seagrasses $(\mathrm{Mg}-\mathrm{Sg})$ and quantitative data on their prey consumption were collected. Trophic flow, defined here as the cross-boundary movement of fish and prey biomass, was examined at $\mathrm{Cr}-\mathrm{Sg}$ and $\mathrm{Mg}-\mathrm{Sg}$ boundaries with special emphasis on the role of Haemulidae (grunts) and Lutjanidae (snappers) due to their abundance in coral reef ecosystems and well documented nocturnal migrations.

Three main questions were addressed through quantitative descriptions and hypothesis testing:

(1) What are the quantities of fish and the biomass of their consumed prey that are moving into and out from coral reefs and mangroves through nocturnal excursions?

(2) Are haemulids (grunts) and lutjanids (snappers) the primary conduits of fish biomass and nutrients into and out from coral reefs and mangroves through nocturnal excursions?

(3) What are the dominant prey items being transported into and out from coral reefs and mangroves through nocturnal excursions? 


\section{METHODS}

\section{Study Area}

Gillnet sampling was conducted during nine surveys from June 2000-December 2002 across the insular shelf off La Parguera, Puerto Rico (Figure 1). Survey missions were conducted every three to four months. The shoreline and islands of the area are lined with mangrove communities dominated by the red mangrove Rhizophora mangle. Adjacent sediments support seagrasses (dominated by Thalassia testudinum), macroalgae and unvegetated sand and sandy mud interspersed with coral reefs and patch reefs, which vary in habitat size and benthic community composition. The tidal range was relatively small $(<0.5 \mathrm{~m})$, and mangrove prop roots at the seaward edge of the mangrove stands were continually immersed throughout the tidal cycle. Water depths for sampled areas ranged from
3-20 $\mathrm{m}$ at $\mathrm{Cr}-\mathrm{Sg}$ sites and 1-3 $\mathrm{m}$ at $\mathrm{Mg}-\mathrm{Sg}$ sites.

\section{Sampling fish}

A digital benthic habitat map (Kendall et al. 2001) displaying only the major habitat types of coral reefs, seagrasses and mangroves was used to randomly select habitat boundaries for sampling within the La Parguera coral reef ecosystem. The habitat map was used to stratify the study area into two unique strata: (1) coral reef/seagrass $(\mathrm{Cr}-\mathrm{S} g$ ) and (2) mangrove/seagrass ( $\mathrm{Mg}-\mathrm{Sg}$ ). During each survey five to eight gillnets were set at each boundary. Gillnets were $100 \mathrm{~m}$ long and had $5 \times 5 \mathrm{~cm}$ nylon mesh size and were deployed along the $\mathrm{Cr}$-Sg habitat boundary running parallel to the reef edge and along the $\mathrm{Mg}-\mathrm{Sg}$ habitat boundary running parallel to the mangrove edge. Nets were set by boat at dusk and retrieved at

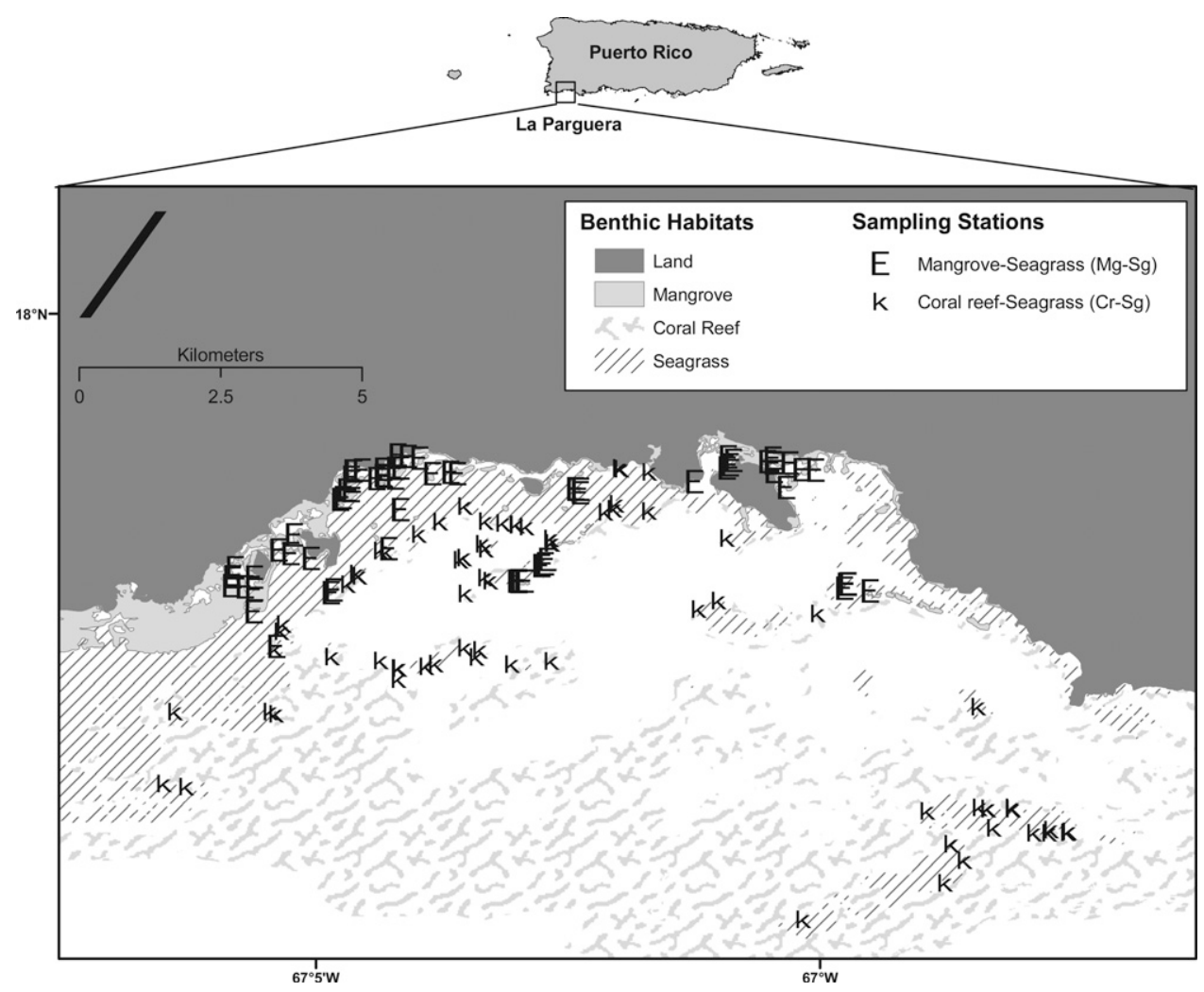

FIG. 1. Location of study area, dominant benthic habitat types using NOAA's benthic habitat map (Kendall et al., 2002) and gillnet sampling sites. 
dawn, with soak times ranging from 12-14 hours.

During net retrieval, the orientation of the fish in the net was recorded; if orientation could not be decided the fish was not used in subsequent analyses. Orientation was used as a predictor of the direction of local movements (Hall et al., 1979). For example, at the $\mathrm{Cr}-\mathrm{Sg}$ boundary, fish that entered the net from the coral reef side were considered to have been leaving the coral reef, while fish on the other side of the net were considered to have been entering the coral reef from adjacent areas dominated by seagrasses. All fish were stored on ice and promptly transported to the laboratory where fish were identified, weighed (wet weight) and lengths measured. Standard length (SL) was used to measure fishes, shark length was measured from the tip of the snout to the precaudal pit, and pectoral fin width was measured for rays. Fishes were assigned to one of four trophic guilds (herbivore, invertivore, piscivore or zooplanktivore) based on prey information from this research, and where information was limited groups were assigned based on Randall (1967) and other sources obtained from FishBase (Froese and Pauly 2009). Entire gastro-intestinal organs were excised and stored in $10 \%$ formalin for 24 hours, then transferred to a 30\% ethanol solution. Stomach contents were removed, wet weighed to the nearest $.001 \mathrm{~g}$, and dietary items were identified to the lowest possible taxon. Ultimately, prey items were grouped into higher taxonomic categories, such as algae, crabs, shrimp, other crustaceans (including isopods, ostracods, or unidentifiable crustaceans), cephalopods, echinoderms, fish, molluscs (including gastropods and bivalves), and seagrass to facilitate statistical analyses. Prey item frequency of occurrence in fish stomachs was used to quantify the importance of prey items to $\mathrm{Cr}$-Sg and $\mathrm{Mg}$-Sg fish communities.

\section{Data analyses}

Mean biomass, density, species richness, prey biomass and prey frequency of ocurrence in fish stomachs was calculated for each net site and segregated by direction of movement. Mean fish morphomet- rics and gut content biomass (including \pm 1 standard error) and frequency of occurrence was compared for each direction at all sites and compared to determine net transfer between habitat types. Gut content biomass was examined by total fish movement, the most abundant families, resident species versus transient species, and for taxa within the families Haemulidae and Lutjanidae. Statistical analyses were conducted using JMP software (SAS Institute, 2006). Differences for paired comparisons between fish movemement and habitat types and gut content directional flow were examined using the Wilcoxon rank sums nonparametric test, since the data could not be transformed to satisfy ANOVA criteria (Zar 1999). Multiple comparisons were conducted using Kruskall-Wallis rank sums test to detect significant differences in fish morphometrics within and among the habitats, flow of prey biomass among the taxonomic groupings, followed by the Nemenyi test to identify the significant factor; statistics were considered significant at $p<0.05$. Correspondence analysis (CA) using reciprocal averaging (Zar 1999) and represented as a two-dimensional ordination plot was used to visually compare the family composition of fish assemblages at $\mathrm{Cr}-\mathrm{S} g$ sites with those at $\mathrm{Mg}$ - $S g$ sites.

\section{Results}

Overall, 57 gillnet deployments at $\mathrm{Cr}-\mathrm{Sg}$ and 64 at $M g-S g$ sites were used for this study. A total of 458 bony and cartilaginous fishes representing 67 species and 33 families were captured using gillnets in the $\mathrm{La}$ Parguera study area (Tables 1 and 2). $\mathrm{Cr}-\mathrm{Sg}$ sites yielded 267 individuals from 56 species and 24 families exhibiting a total biomass of $210.99 \mathrm{~kg}$. Mean fish length (standard length, SL), excluding cartilaginous species was $24.2 \mathrm{~cm}(\mathrm{SE} \pm 0.59)$, with the smallest fish measuring $9.4 \mathrm{~cm}$ and the largest $73 \mathrm{~cm}$. Seven individuals from three species of cartilaginous fishes were captured, with a total biomass of $43.53 \mathrm{~kg}$. $M g$-Sg sites yielded 191 individuals from 29 species and 21 families, with a total biomass of $196.29 \mathrm{~kg}$. Mean fish length (SL), excluding cartilaginous fishes, at $\mathrm{Mg}-\mathrm{Sg}$ sites was 
TABLE 1. Summary morphometrics for all species captured at $\mathrm{Cr}$-Sg boundaries. Species names followed by $-\mathrm{c}$ indicate cartilaginous fishes. Trophic groups: inv=invertivore, $\mathrm{h}=$ herbivore, $\mathrm{p}=$ piscivore, $\mathrm{z}=\mathrm{zooplanktivore}$. Length is standard length (SL) for fishes; snout to precaudal pit length for sharks; and pectoral fin width for rays.

\begin{tabular}{|c|c|c|c|c|c|c|c|}
\hline Species & Family & $\begin{array}{c}\text { Trophic } \\
\text { group }\end{array}$ & Abundance & $\begin{array}{l}\text { Length } \\
\text { min }(\mathrm{cm})\end{array}$ & $\begin{array}{l}\text { Length } \\
\max (\mathrm{cm})\end{array}$ & $\begin{array}{l}\text { Biomass } \\
\min (\mathrm{kg})\end{array}$ & $\begin{array}{c}\text { Biomass } \\
\max (\mathrm{kg})\end{array}$ \\
\hline Acanthurus bahianus & Acanthuridae & $\mathrm{h}$ & 2 & 16.4 & 17.9 & 0.142 & 0.241 \\
\hline Acanthurus chirurgus & Acanthuridae & $\mathrm{h}$ & 6 & 16.4 & 22.2 & 0.195 & 0.395 \\
\hline Acanthurus coeruleus & Acanthuridae & $\mathrm{h}$ & 13 & 14.3 & 18.3 & 0.17 & 0.35 \\
\hline Aetobatus narinari-c & Myliobatidae & inv & 1 & 50.6 & 50.6 & 8.9 & 8.9 \\
\hline Albula vulpes & Albulidae & inv & 1 & 27.2 & 27.2 & 0.345 & 0.345 \\
\hline Anisotremus virginicus & Haemulidae & inv & 1 & 21.5 & 21.5 & 0.352 & 0.352 \\
\hline Calamus bajonado & Sparidae & inv & 3 & 21.1 & 22.2 & 0.35 & 0.397 \\
\hline Calamus calamus & Sparidae & inv & 20 & 17.5 & 35.1 & 0.196 & 1.634 \\
\hline Calamus penna & Sparidae & inv & 9 & 19.7 & 22.8 & 0.3 & 0.446 \\
\hline Calamus pennatula & Sparidae & inv & 3 & 19.5 & 22.4 & 0.276 & 0.365 \\
\hline Caranx bartholomaei & Carangidae & $\mathrm{p}$ & 1 & 31.4 & 31.4 & 0.704 & 0.704 \\
\hline Caranx hippos & Carangidae & $\mathrm{p}$ & 3 & 28.3 & 47.4 & 0.649 & 2.473 \\
\hline Caranx latus & Carangidae & $\mathrm{p}$ & 7 & 26.1 & 54.8 & 0.499 & 3.592 \\
\hline Caranx ruber & Carangidae & $\mathrm{p}$ & 12 & 18.7 & 62 & 0.166 & 5.525 \\
\hline Carcharhinus perezi-c & Carcharhinidae & $\mathrm{p}$ & 1 & 74.8 & 74.8 & 2.245 & 2.245 \\
\hline Chaetodipterus faber & Ephippidae & inv & 3 & 15.6 & 16.8 & 0.257 & 0.329 \\
\hline Chloroscomburs chrysurus & Carangidae & $\mathrm{p}$ & 8 & 11.2 & 17.2 & 0.032 & 0.109 \\
\hline Dactylopterus volitans & Dactylopteridae & inv & 1 & 23.3 & 23.3 & 0.254 & 0.254 \\
\hline Dasyatis americana-c & Dasyatidae & inv & 5 & 43.3 & 65.8 & 3.958 & 9.45 \\
\hline Diodon holocanthus & Tetraodontidae & inv & 3 & 25.5 & 42.5 & 0.746 & 2.921 \\
\hline Diodon hystrix & Tetraodontidae & inv & 8 & 13.7 & 44.1 & 0.227 & 3.96 \\
\hline Echeneis naucrates & Echeneidae & inv & 4 & 20.4 & 47.5 & 0.193 & 3.066 \\
\hline Gerres cinereus & Gerreidae & inv & 8 & 21.7 & 26.9 & 0.341 & 0.543 \\
\hline Haemulon aurolineatum & Haemulidae & inv & 3 & 12.5 & 13 & 0.036 & 0.055 \\
\hline Haemulon chrysargyreum & Haemulidae & inv & 1 & 9.4 & 9.4 & 0.019 & 0.019 \\
\hline Haemulon flavolineatum & Haemulidae & inv & 3 & 12.1 & 13.2 & 0.054 & 0.076 \\
\hline Haemulon parra & Haemulidae & inv & 2 & 27.1 & 29.9 & 0.603 & 0.632 \\
\hline Haemulon plumieri & Haemulidae & inv & 17 & 16 & 24.2 & 0.113 & 0.4 \\
\hline Haemulon sciurus & Haemulidae & inv & 17 & 14.4 & 26.5 & 0.092 & 0.471 \\
\hline Haemulon striatum & Haemulidae & inv & 2 & 11.3 & 13.5 & 0.035 & 0.069 \\
\hline Holocentrus adscensionis & Holocentridae & inv & 3 & 10.2 & 13.6 & 0.047 & 0.322 \\
\hline Holocentrus marianus & Holocentridae & inv & 1 & 16.2 & 16.2 & 0.086 & 0.086 \\
\hline Holocentrus rufus & Holocentridae & inv & 2 & 15 & 15.7 & 0.078 & 0.08 \\
\hline Kyphosus sectatrix/incisor & Kyphosidae & $\mathrm{h}$ & 23 & 22 & 32.4 & 0.417 & 1.179 \\
\hline Lachnolaimus maximus & Labridae & inv & 2 & 20.2 & 22.3 & 0.342 & 0.436 \\
\hline Lactophrys trigonus & Ostraciidae & inv & 1 & 32.5 & 32.5 & 0.898 & 0.898 \\
\hline Lutjanus analis & Lutjanidae & $\mathrm{p}$ & 3 & 28 & 31.3 & 0.597 & 0.839 \\
\hline Lutjanus apodus & Lutjanidae & $\mathrm{p}$ & 1 & 25.8 & 25.8 & 0.598 & 0.598 \\
\hline Lutjanus cyanopterus & Lutjanidae & $\mathrm{p}$ & 1 & 29.2 & 29.2 & 0.66 & 0.66 \\
\hline Lutjanus griseus & Lutjanidae & $\mathrm{p}$ & 8 & 28 & 34.4 & 0.556 & 0.974 \\
\hline Lutjanus jocu & Lutjanidae & $\mathrm{p}$ & 5 & 21.8 & 29.8 & 0.317 & 0.912 \\
\hline Lutjanus synagris & Lutjanidae & $\mathrm{p}$ & 1 & 16.8 & 16.8 & 0.148 & 0.148 \\
\hline Mulloidichthys martinicus & Mullidae & inv & 2 & 15 & 22 & 0.093 & 0.268 \\
\hline Myripristis jacobus & Holocentridae & $\mathrm{z}$ & 4 & 12.1 & 12.9 & 0.075 & 0.098 \\
\hline Ocyurus chrysurus & Lutjanidae & $\mathrm{p}$ & 2 & 31.5 & 31.9 & 0.612 & 0.732 \\
\hline Pomacanthus arcuatus & Pomacanthidae & inv & 4 & 10.5 & 19 & 0.094 & 0.528 \\
\hline Scarus guacamaia & Scaridae & $\mathrm{h}$ & 1 & 25.9 & 25.9 & 0.664 & 0.664 \\
\hline Scarus vetula & Scaridae & $\mathrm{h}$ & 2 & 29.8 & 29.9 & 0.912 & 1.007 \\
\hline Scomberomorus regalis & Scombridae & $\mathrm{p}$ & 4 & 41.1 & 45.6 & 0.824 & 1.085 \\
\hline Scorpaena plumieri & Scorpaenidae & $\mathrm{p}$ & 6 & 14.3 & 20.2 & 0.147 & 0.409 \\
\hline
\end{tabular}


TABle 1. Continued.

\begin{tabular}{llcccccc}
\hline \hline Species & \multicolumn{1}{c}{ Family } & $\begin{array}{c}\text { Trophic } \\
\text { group }\end{array}$ & Abundance & $\begin{array}{c}\text { Length } \\
\text { min }(\mathrm{cm})\end{array}$ & $\begin{array}{c}\text { Length } \\
\max (\mathrm{cm})\end{array}$ & $\begin{array}{c}\text { Biomass } \\
\min (\mathrm{kg})\end{array}$ & $\begin{array}{c}\text { Biomass } \\
\max (\mathrm{kg})\end{array}$ \\
\hline Selar crumenophthalamus & Carangidae & $\mathrm{z}$ & 9 & 17.1 & 18.5 & 0.103 & 0.143 \\
Sparisoma chrysopterum & Scaridae & $\mathrm{h}$ & 1 & 27.6 & 27.6 & 0.724 & 0.724 \\
Sparisoma aurofrenatum & Scaridae & $\mathrm{h}$ & 4 & 14 & 35.1 & 0.133 & 1.548 \\
Sparisoma viride & Scaridae & $\mathrm{h}$ & 2 & 24.3 & 27.5 & 0.542 & 0.649 \\
Synodus intermedius & Synodontidae & $\mathrm{p}$ & 5 & 24.2 & 28.4 & 0.21 & 0.318 \\
Trachinotus falcatus & Carangidae & inv & 2 & 63.4 & 73 & 9.5 & 11.6 \\
\hline
\end{tabular}

TABLE 2. Summary morphometrics for all species captured at $M g$ - $S g$ boundaries. Species names followed by $-\mathrm{c}$ indicate cartilaginous fishes. Trophic groups: inv=invertivore, $\mathrm{h}=$ herbivore, $\mathrm{p}=\mathrm{piscivore}, \mathrm{z}=\mathrm{zooplanktivore}$. Length is standard length (SL) for fishes; snout to precaudal pit length for sharks; and pectoral fin width for rays.

\begin{tabular}{|c|c|c|c|c|c|c|c|}
\hline Species & Family & $\begin{array}{l}\text { Trophic } \\
\text { group }\end{array}$ & Abundance & $\begin{array}{l}\text { Length } \\
\min (\mathrm{cm})\end{array}$ & $\begin{array}{l}\text { Length } \\
\max (\mathrm{cm})\end{array}$ & $\begin{array}{l}\text { Biomass } \\
\min (k g)\end{array}$ & $\begin{array}{l}\text { Biomass } \\
\max (\mathrm{kg})\end{array}$ \\
\hline Aetobatus narinari-c & Myliobatidae & inv & 2 & 42.1 & 44.5 & 0.94 & 1.157 \\
\hline Archosargus rhomboidalis & Sparidae & $\mathrm{h}$ & 36 & 16.6 & 21.3 & 0.197 & 0.319 \\
\hline Bothus lunatus & Bothidae & inv & 3 & 13.7 & 17.5 & 0.059 & 0.124 \\
\hline Caranx hippos & Carangidae & $\mathrm{p}$ & 1 & 55.6 & 55.6 & 3.752 & 3.752 \\
\hline Caranx ruber & Carangidae & $\mathrm{p}$ & 1 & 33.5 & 33.5 & 0.781 & 0.781 \\
\hline Centropomus undecimalis & Centropomidae & $\mathrm{p}$ & 4 & 39.1 & 43 & 0.651 & 1.323 \\
\hline Chaetodipterus faber & Ephippidae & inv & 7 & 13.9 & 30.4 & 0.187 & 1.852 \\
\hline Dasyatis americana-c & Dasyatidae & inv & 10 & 45.1 & 66.3 & 3.921 & 12 \\
\hline Diodon holocanthus & Tetraodontidae & inv & 5 & 22.5 & 35.2 & 0.548 & 1.97 \\
\hline Diodon hystrix & Tetraodontidae & inv & 14 & 22.5 & 41.6 & 0.556 & 3.052 \\
\hline Gerres cinereus & Gerreidae & inv & 11 & 20.3 & 25.9 & 0.249 & 0.589 \\
\hline Ginglymostoma cirratum-c & Rhincodontidae & $\mathrm{p}$ & 1 & 130 & 130 & 10 & 10 \\
\hline Gymnothorax funebris & Muraenidae & $\mathrm{p}$ & 1 & 96.7 & 96.7 & 1.75 & 1.75 \\
\hline Haemulon sciurus & Haemulidae & inv & 24 & 10.6 & 21.6 & 0.038 & 0.267 \\
\hline Lactophrys trigonus & Ostraciidae & inv & 2 & 17.4 & 18.6 & 0.196 & 1.593 \\
\hline Lutjanus analis & Lutjanidae & $\mathrm{p}$ & 3 & 28.4 & 29.5 & 0.25 & 0.693 \\
\hline Lutjanus apodus & Lutjanidae & $\mathrm{p}$ & 1 & 17.7 & 17.7 & 0.177 & 0.177 \\
\hline Lutjanus cyanopterus & Lutjanidae & $\mathrm{p}$ & 2 & 44.2 & 49.6 & 2.551 & 3.512 \\
\hline Lutjanus griseus & Lutjanidae & $\mathrm{p}$ & 27 & 16.9 & 41.3 & 0.147 & 1.754 \\
\hline Lutjanus jocu & Lutjanidae & $\mathrm{p}$ & 13 & 21.5 & 35.2 & 0.307 & 1.16 \\
\hline Megalops atlanticus & Elopidae & $\mathrm{p}$ & 5 & 37.9 & 44.9 & 0.876 & 1.397 \\
\hline Mugil curema & Mugilidae & inv & 1 & 28.9 & 28.9 & 0.508 & 0.508 \\
\hline Peprilus alepidotus & Stromateidae & inv & 1 & 14.2 & 14.2 & 0.165 & 0.165 \\
\hline Scorpaena plumieri & Scorpaenidae & $\mathrm{p}$ & 5 & 12.9 & 20.3 & 0.111 & 0.424 \\
\hline Selene vomer & Carangidae & $\mathrm{z}$ & 2 & 12.8 & 21.1 & 0.069 & 0.325 \\
\hline Sphyraena barracuda & Sphyraenidae & $\mathrm{p}$ & 2 & 25.5 & 30.9 & 0.147 & 0.251 \\
\hline Synodus intermedius & Synodontidae & $\mathrm{p}$ & 2 & 16.9 & 21 & 0.075 & 0.119 \\
\hline Trachinotus falcatus & Carangidae & inv & 2 & 35.9 & 64 & 1.697 & 8.1 \\
\hline Trinectes maculatus & Soleidae & inv & 3 & 14.2 & 18 & 0.149 & 0.302 \\
\hline
\end{tabular}

$24.54 \mathrm{~cm}$ ( $\mathrm{SE} \pm 0.81$ ), where the smallest fish was $10.6 \mathrm{~cm}$ and the largest was $64.0 \mathrm{~cm}$. Thirteen individuals from three species of cartilaginous species were captured at $\mathrm{Mg}-\mathrm{Sg}$ with a total biomass of $77.82 \mathrm{~kg}$. Abundance and species richness were significantly greater at $\mathrm{Cr}-\mathrm{Sg}$ sites $(\mathrm{p}=0.0014$ and $\mathrm{p}=0.0005$, respectively) than at $\mathrm{Mg}-\mathrm{Sg}$ sites. Mean fish biomass did not differ between the two habitats.

Invertivorous fish were the most abundant trophic group, with highest biomass $(\mathrm{p}<0.0001)$ at both $\mathrm{Cr}-\mathrm{Sg}$ and $\mathrm{Mg}$-Sg sites (Figure 2a,b). Piscivores were significantly $(\mathrm{p}<0.0001)$ more abundant and with greater biomass than herbivores only at $\mathrm{Mg}$-Sg sites. 
Zooplanktivores were comparatively rare in gillnet samples, exhibiting lower abundance and biomass than all other trophic groups.

Fish assemblage composition was significantly different $\left(\chi^{2}<0.0001\right)$ between $C r-S g$ and $M g$-Sg sites (Figure 3). Although overlap among families occurred frequently between the two habitat strata, actual species composition often differed. For example, Sparidae were abundant at both $\mathrm{Cr}$-Sg and $M g$-Sg boundaries, but Archosargus spp. were more prevalent at $M g$-Sg sites, while Calamus spp. were more prevalent at $\mathrm{Cr}-\mathrm{Sg}$ sites (Tables 1 and 2). Lutjanidae, Sparidae, and Haemulidae comprised $55 \%$ of the total abundance at $\mathrm{Mg}$-Sg sites, while at $\mathrm{Cr}$-Sg sites Haemulidae, Carangidae, Sparidae,

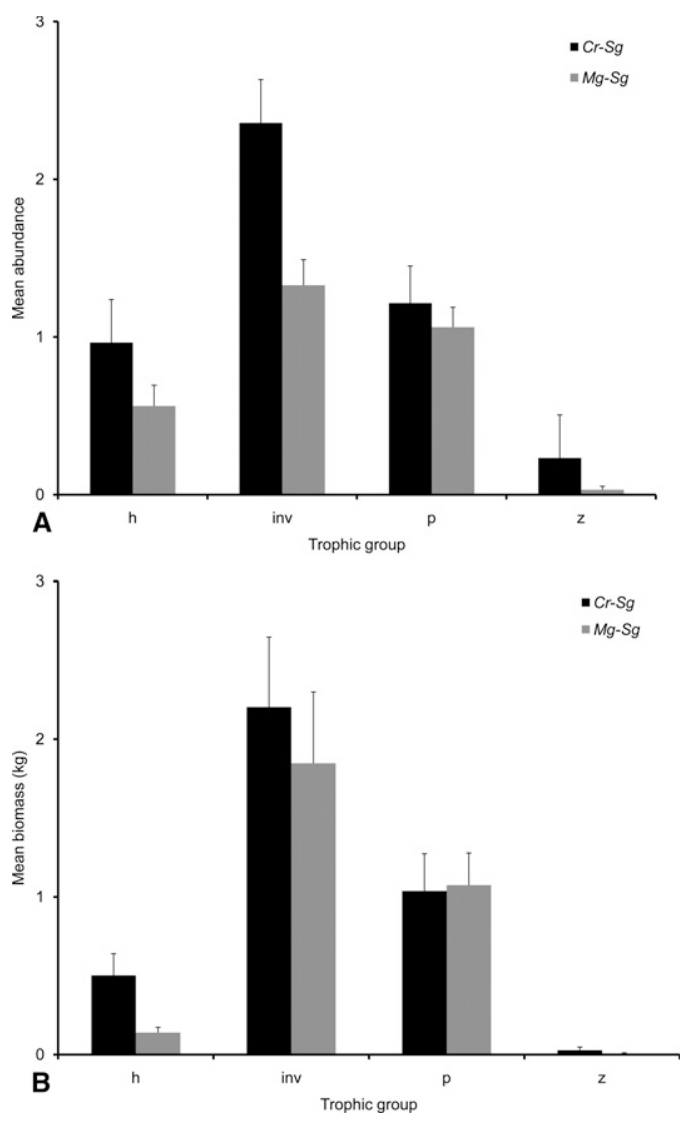

FIG. 2. Mean bidirectional (a) abundance and (b) biomass ( \pm 1SE) for fish trophic guilds captured at $\mathrm{Cr}$-Sg boundaries and $\mathrm{Mg}-\mathrm{Sg}$ boundaries. $\mathrm{h}=$ herbivore, inv=invertivore, $\mathrm{p}=$ piscivores, $\mathrm{z}=$ zooplanktivore.
Kyphosidae and Lutjanidae comprised $62 \%$ of the total abundance (Table 3). Biomass was mainly comprised of individuals from Dasyatidae, Lutjanidae, and Tetraodontidae accounting for $67 \%$ of total fish biomass at $\mathrm{Mg}-\mathrm{Sg}$ sites, while Carangidae, Dasyatidae, Tetraodontidae, and Kyphosidae yielded the most biomass (60\% of fish biomass) at $\mathrm{Cr}-\mathrm{Sg}$ sites.

\section{Nocturnal fish movements in and out of mangroves and coral reefs}

Fish assemblage.-Trophic flow, or the flow of fish species, their biomass, and ingested prey biomass into or out of a particular habitat type, was greatest at $\mathrm{Cr}-\mathrm{Sg}$ sites (Figure 4). Mean fish density, biomass and species richness were greater leaving than entering $\mathrm{Cr}$ habitats at night, yet only fish species richness was statistically significant $(p=0.0018)$. Mean prey biomass entering $\mathrm{Cr}$ habitats at night $(26.8, \mathrm{SD}=72.25)$ was almost three times higher than that leaving $\mathrm{Cr}(10.2, \mathrm{SD}=16.47)$ resulting in a mean net transfer of prey biomass of $0.016 \mathrm{~kg}$ from $\mathrm{Sg}$ to $\mathrm{Cr}$; however this relationship was not statistically significant. Mean fish abundance, biomass, and species richness were greater leaving $M g$ habitats at night than entering $M g$, although none were statistically significant. Furthermore, mean prey biomass was not statistically greater entering (mean=4.79, $\mathrm{SD}=11.22$ ) or leaving $M g$ (mean=11.36, SD=27.42) but was almost three times greater leaving $M g$ (Figure 4). Total prey biomass was comparable for fish leaving both $\mathrm{Cr}$ and $\mathrm{Mg}$ habitats; however, prey biomass transport (not statistically significant) into $\mathrm{Cr}$ was five times greater than that observed at $M g$.

Fish trophic groups.-Examining prey biomass by trophic group revealed that invertivores were the primary transporters of prey biomass (Figure 5). Invertivores accounted for $48 \%$ of prey biomass entering $\mathrm{Cr}$ habitats at night and $41 \%$ leaving $\mathrm{Cr}$. Invertivores accounted for $35 \%$ of prey biomass entering $M g$ and $81 \%$ leaving $M g$ at night. Herbivores were the second highest source of incoming prey biomass from fish averaging $36 \%$ of the prey biomass entering 


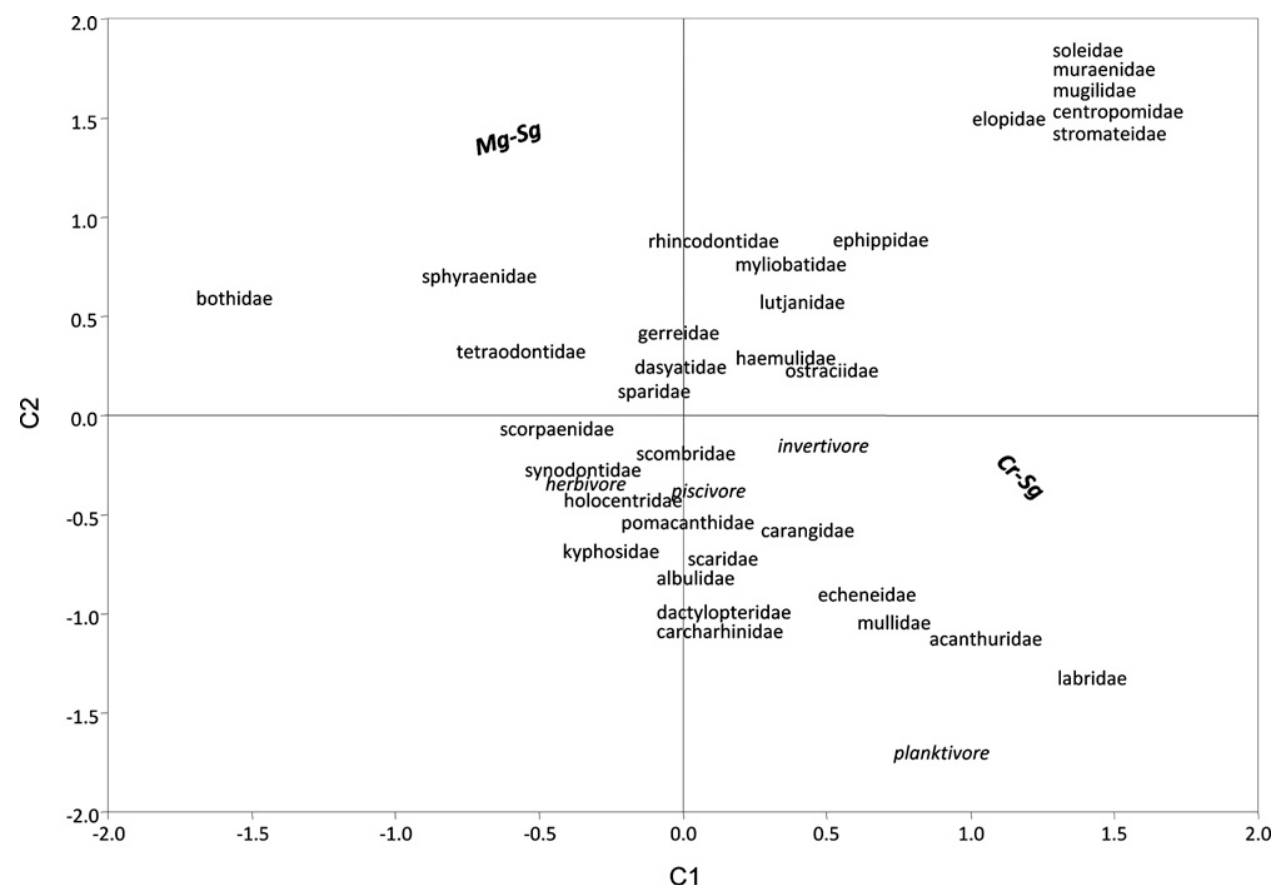

FIG. 3. Correspondence analysis (CA) ordination plot displaying fish family and trophic group composition for all gillnet samples at $\mathrm{Cr}-\mathrm{Sg}$ and $\mathrm{Mg}-\mathrm{Sg}$ boundaries.

$\mathrm{Cr}$, but exhibited high variability. Piscivores accounted for $20 \%$ of the total prey biomass entering $\mathrm{Cr}$ at night and $12 \%$ of the prey biomass leaving $\mathrm{Cr}$. The prey biomass within piscivores entering $\mathrm{Mg}$ from adjacent areas at night was $37 \%$ of the total and piscivore prey accounted for $11 \%$ of the total prey leaving $M g$.

Fish families.-Of the 24 families captured at $\mathrm{Cr}-\mathrm{Sg}$, prey transport was primarily accomplished by eight families (Figure 6a). Approximately $70 \%$ of prey biomass entering $\mathrm{Cr}$ habitats was transported by Kyphosidae and Carangidae, while only $4 \%$ was transported by Sparidae and Lutjanidae. Fish from Kyphosidae were the predominant movers of prey biomass out of $\mathrm{Cr}$ habitats (33\%) followed by Lutjanidae $(11 \%)$, Sparidae $(10 \%)$ and Carangidae (7\%). Seven of twenty one families transported the majority of prey biomass across $\mathrm{Mg}-\mathrm{Sg}$ boundaries (Figure 6b). Sparidae, Lutjanidae, and Dasyatidae accounted for $79 \%$ of the total prey biomass imported into $M g$ (Figure 6b). Fish from the families
Dasyatidae, Carangidae, Tetraodontidae, and Sparidae accounted for $80 \%$ of total prey biomass leaving $M g$ at night.

The families were further pooled to represent resident and transient species. As a whole, resident families transported $62.7 \%$ of bidirectional prey biomass at $\mathrm{Cr}-\mathrm{Sg}$. For resident species, transfer of prey biomass (Figure 7a) was greater from $\mathrm{Sg}$ to $\mathrm{Cr}(0.014$ $\mathrm{kg} \pm 0.006)$ compared to $C r-S g(0.008 \mathrm{~kg} \pm$ $0.001)$. Transient species displayed a greater prey biomass net transfer from $\mathrm{Sg}$ to $\mathrm{Cr}$ $(0.012 \pm 0.007)$ compared to $\mathrm{Cr}$ to $S g(0.0016$ \pm 0.0012 ). Prey biomass transfer was not statistically significant for resident or transient directional flow. Only $53 \%$ of prey biomass was transported by resident species at Mg-Sg. Resident families prey biomass (Figure $7 \mathrm{~b}$ ) was greater from $\mathrm{Mg}$ to $\mathrm{Sg}(0.005 \pm 0.0011)$ in comparison to Sg to $\mathrm{Mg}(0.003 \pm 0.0009)$ and was not statistically significant. Conversely, transient families transferred significantly greater prey biomass $(p<0.0001)$ from $\mathrm{Mg}$ to $\mathrm{Sg}(0.006$ $\pm 0.002)$ compared with $\mathrm{Sg}$ to $\mathrm{Mg}(0.0012 \pm$ 0.0011). 
TABLE 3. Total abundance and biomass for fish families captured at $C r-S g$ and $M g$ - $S g$ boundaries.

\begin{tabular}{|c|c|c|c|c|}
\hline \multirow[b]{2}{*}{ Family } & \multicolumn{2}{|c|}{ Reef } & \multicolumn{2}{|c|}{ Mangrove } \\
\hline & Abundance & Biomass (kg) & Abundance & Biomass $(\mathrm{kg})$ \\
\hline Haemulidae & 46 & 12.38 & 24 & 2.11 \\
\hline Carangidae & 42 & 57.46 & 6 & 14.72 \\
\hline Sparidae & 35 & 14.59 & 36 & 8.93 \\
\hline Kyphosidae & 23 & 16.39 & & \\
\hline Lutjanidae & 21 & 14.08 & 46 & 40.53 \\
\hline Acanthuridae & 21 & 5.29 & & \\
\hline Tetraodontidae & 11 & 21.07 & 19 & 25.69 \\
\hline Scaridae & 10 & 6.41 & & \\
\hline Holocentridae & 10 & 1.00 & & \\
\hline Scorpaenidae & 6 & 1.60 & 5 & 1.28 \\
\hline Dasyatidae & 5 & 32.39 & 10 & 65.73 \\
\hline Synodontidae & 5 & 1.29 & 2 & 0.19 \\
\hline Echeneidae & 4 & 4.28 & & \\
\hline Scombridae & 4 & 3.64 & & \\
\hline Pomacanthidae & 4 & 1.06 & & \\
\hline Labridae & 2 & 0.78 & & \\
\hline Mullidae & 2 & 0.36 & & \\
\hline Myliobatidae & 1 & 8.90 & 2 & 2.10 \\
\hline Ostraciidae & 1 & 0.90 & 2 & 1.79 \\
\hline Carcharhinidae & 1 & 2.25 & & \\
\hline Albulidae & 1 & 0.35 & & \\
\hline Dactylopteridae & 1 & 0.25 & & \\
\hline Elopidae & & & 5 & 5.84 \\
\hline Centropomidae & & & 4 & 4.25 \\
\hline Muraenidae & & & 1 & 1.75 \\
\hline Soleidae & & & 3 & 0.69 \\
\hline Mugilidae & & & 1 & 0.51 \\
\hline Sphyraenidae & & & 2 & 0.40 \\
\hline Bothidae & & & 3 & 0.26 \\
\hline Stromateidae & & & 1 & 0.17 \\
\hline
\end{tabular}

Importance of grunts and snappers in the nocturnal trophic flux in coral reef ecosystems

Lutjanidae.-As a family, snappers were captured in $25 \%$ of $\mathrm{Cr}-\mathrm{Sg}$ gillnet sets and $51 \%$ of $\mathrm{Mg}-\mathrm{Sg}$. Of the total fish captured,
$14.6 \%$ were snappers (67 individuals from seven species) (Tables 1 and 2). Lutjanus griseus (gray snapper) and L. jocu (dog snapper) were the most abundant lutjanid species at both the $\mathrm{Cr}$-Sg boundary and the

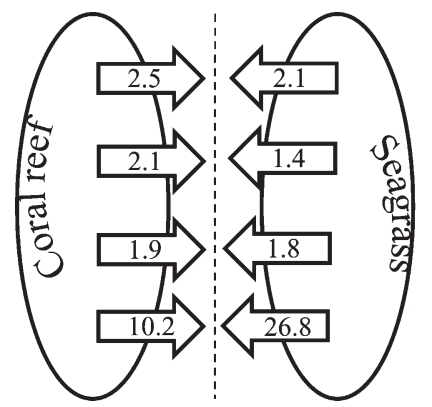

Density (fish/100m)

Species richness (species $/ 100 \mathrm{~m})$

Fish biomass (kg/100m)

Prey biomass (g/100m)

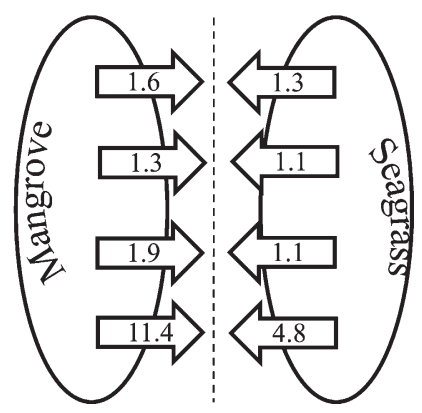

FIG. 4. Transfer of mean fish density, biomass, species richness and prey biomass between $C r-S g$ and $M g$ - $S g$ boundaries. Arrows indicate the direction in which fish were travelling when captured. Broken line represents the gillnet. 


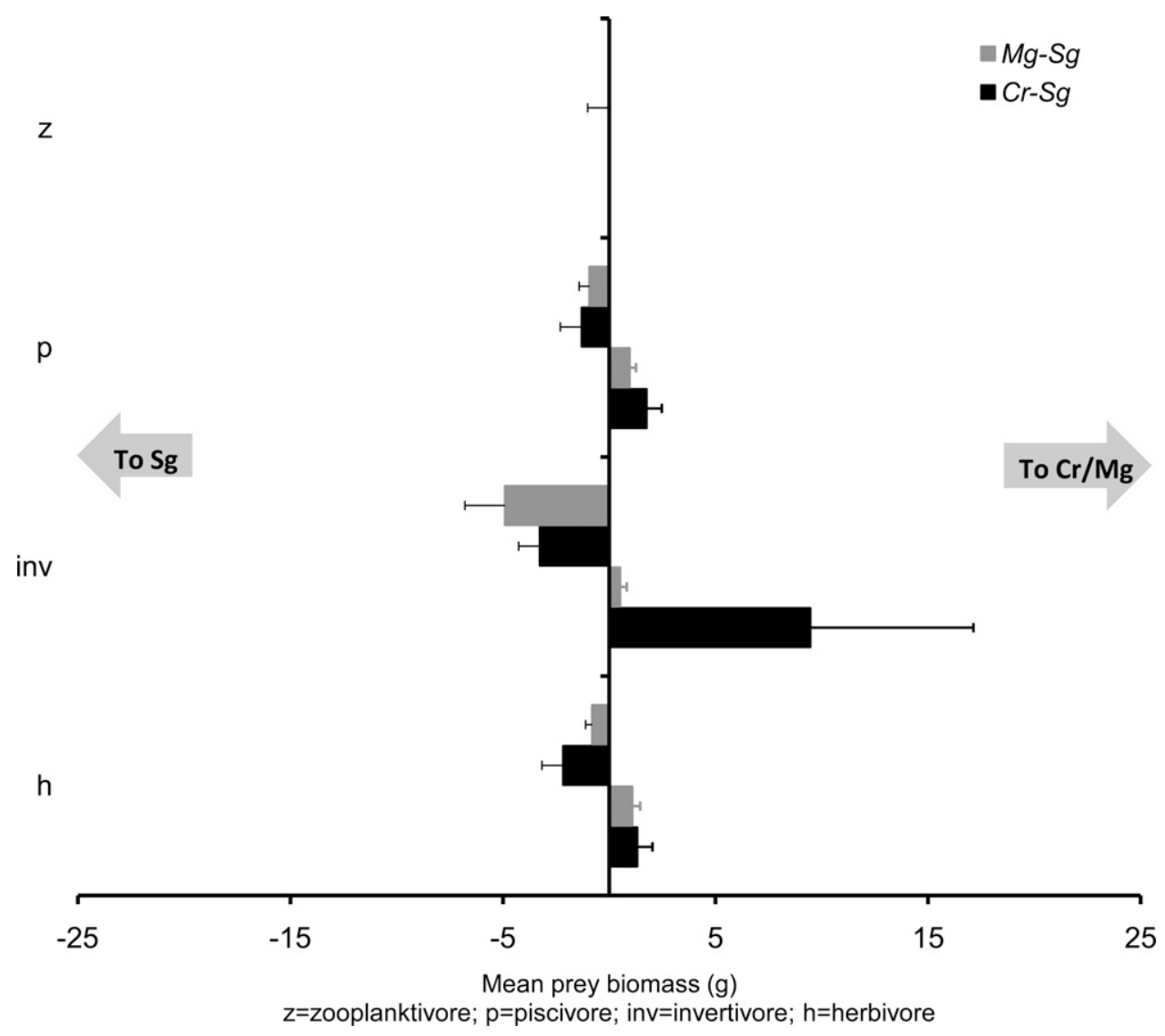

Fig. 5. Mean prey biomass ( $\pm 1 \mathrm{SE}$ ) transported by fish trophic groups between $C r-S g$ and $M g-S g$ boundaries. Negative values indicate movement into $S g$, positive values indicate movement into $\mathrm{Cr}$ or $\mathrm{Mg}$.

$\mathrm{Mg}-\mathrm{Sg}$ boundary, but overall lutjanids were more abundant at $\mathrm{Mg}$-Sg sites. Mean size and biomass of L. griseus at Cr-30.6 cm SL $( \pm 0.65), 0.76 \mathrm{~kg}( \pm 0.04)$, and at $M g-31.6 \mathrm{~cm}$ SL ( \pm 1.1$), 0.89 \mathrm{~kg}( \pm 0.07)(C r-30.6 \mathrm{~cm} \mathrm{SL}$, $0.76 \mathrm{~kg} ; \mathrm{Mg}-31.6 \mathrm{~cm}$ SL, $0.89 \mathrm{~kg}$ ) were not significantly different between $L$. jocu size and biomass at $\mathrm{Cr}-25.6 \mathrm{~cm}$ SL $( \pm 1.3), 0.59$ $\mathrm{kg}( \pm 0.09)$ or $M g-27.8 \mathrm{~cm} \mathrm{SL}( \pm 1.2), 0.64 \mathrm{~kg}$ $( \pm 0.06)$. Snapper movements resulted in a net transfer of $0.36 \mathrm{~kg}( \pm 0.27 \mathrm{~kg})$ biomass from $\mathrm{Cr}$ to $S g$ and a net transfer of $0.29 \mathrm{~kg}$ $( \pm 0.21 \mathrm{~kg})$ from $M g$ to $S g$. Total snapper prey biomass flow exhibited similar patterns where net transfer from $\mathrm{Cr}$ to $\mathrm{Sg}$ of $0.001 \mathrm{~kg}$ $( \pm 0.003 \mathrm{~kg})$ was observed and net transfer of $0.0007 \mathrm{~kg}$ ( $\pm 0.0015 \mathrm{~kg}$ ) from $M g$ to $S g$. Of the most abundant snappers, $L$. jocu exhibited net transfers of prey biomass from $S g$ to $\mathrm{Cr}$ and $\mathrm{Sg}$ to $\mathrm{Mg}$, while L. griseus exhibited net transfer of biomass from $\mathrm{Cr}$ and $\mathrm{Mg}$ to $\mathrm{Sg}$ (Figure 8a). Snappers transported $5 \%$ of total prey biomass at $\mathrm{Cr}-\mathrm{Sg}$ sites and $14 \%$ at $M g-S g$. Fish comprised the majority of snapper prey biomass at both $C r-S g$ and $\mathrm{Mg}-\mathrm{Sg}$ sites (Figure 9a) and represent the essential prey item for the family as a whole (Table 4). Fish were the principal dietary item for L. griseus and L. jocu at Cr-Sg, while crabs appeared to be the primary prey item for $L$. analis. Crab frequency and biomass was greater for snappers at $\mathrm{Mg}$-Sg; however, fish were the most important for the family as a group and for L. griseus. Crabs were the primary prey item for $L$. jocu at $\mathrm{Mg}$-Sg. Shrimp were a minor item for snappers at $\mathrm{Cr}-\mathrm{Sg}$, but increased considerably for snappers at $M g-S g$ (Table 4). 


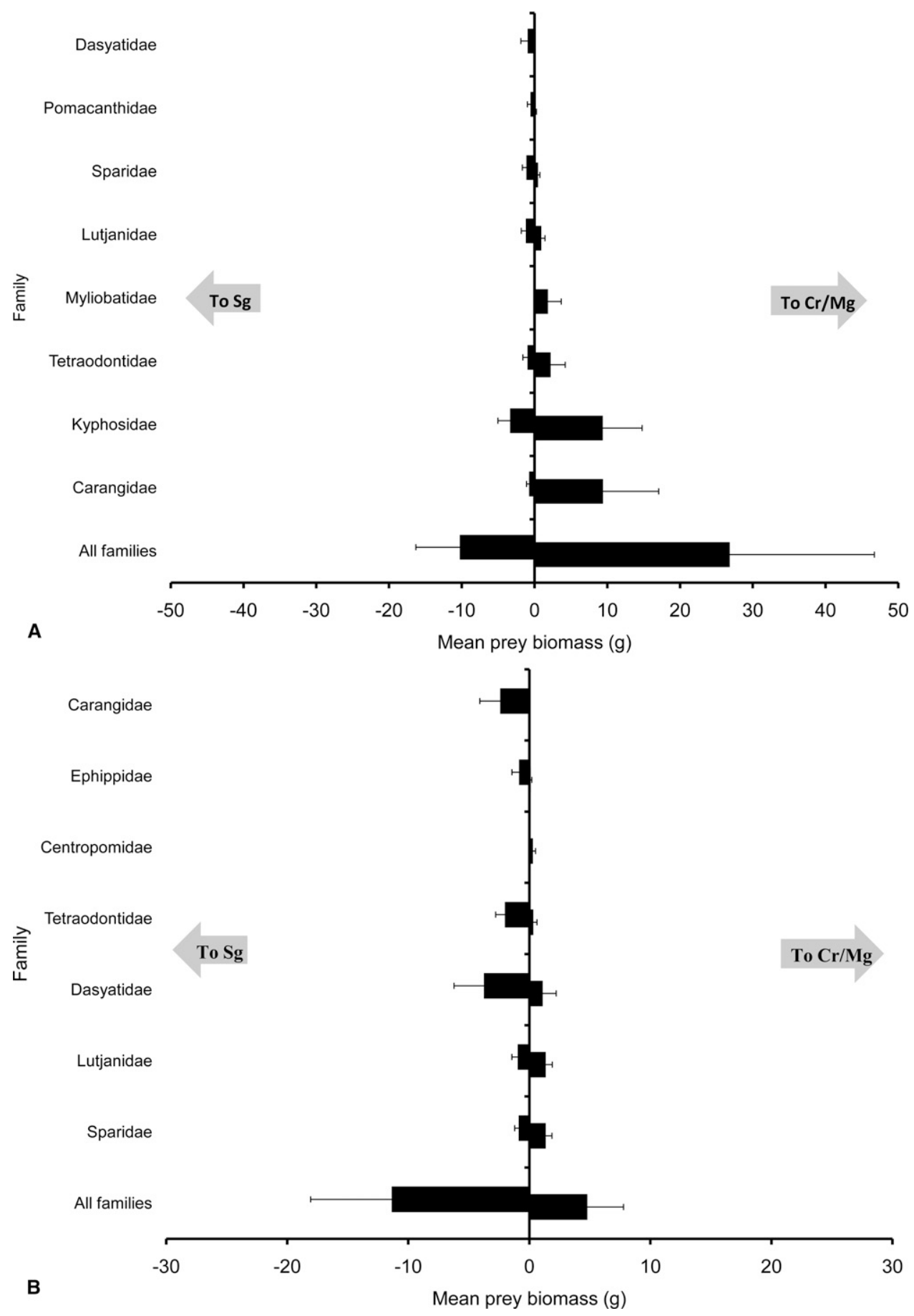

FIG. 6. Mean prey biomass ( \pm 1SE) grouped by family for fish moving in and out of: (a) $C r-S g$, and (b) $M g-S g$. Negative values indicate movement into $\mathrm{Sg}$, positive values indicate movement into $\mathrm{Cr}$ or $\mathrm{Mg}$. 


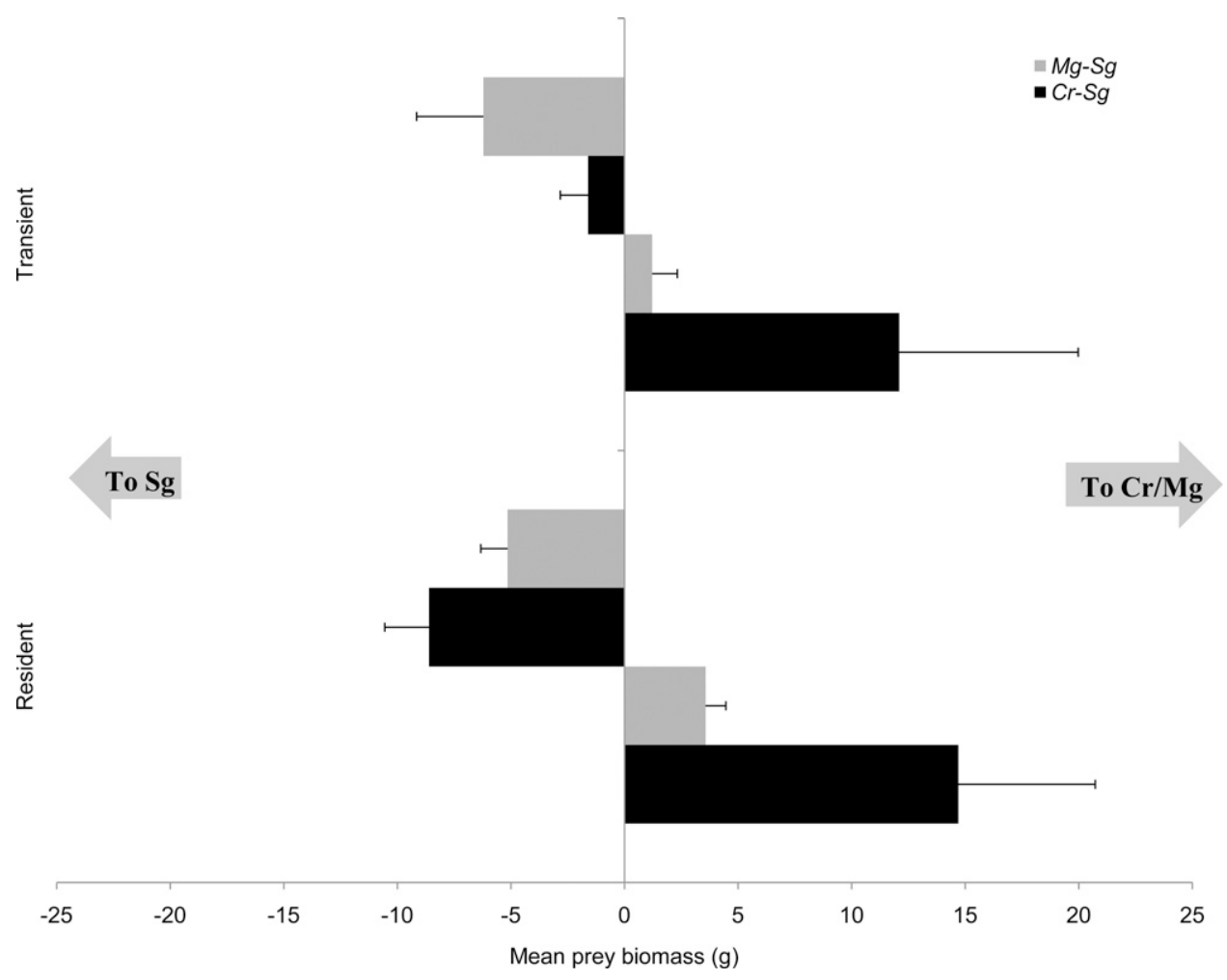

FIG. 7. Mean prey biomass ( \pm 1SE) transported by resident and transient species between $C r-S g$ and $M g-S g$ boundaries. Negative values indicate movement into $\mathrm{Sg}$, positive values indicate movement into $\mathrm{Cr}$ or $\mathrm{Mg}$.

Haemulidae.-Grunts were captured at $47 \%$ of $\mathrm{Cr}$ - $\mathrm{Sg}$ sites and $28 \%$ of $\mathrm{Mg}$-Sg sites. Grunts accounted for $15.3 \%$ of all fish captured (70 individuals from eight species). Eight species of grunt were captured at the $\mathrm{Cr}$-Sg boundary, while only one species, Haemulon sciurus (bluestriped grunt) was captured at $M g$-Sg sites (Tables 1, 2). Mean $H$. sciurus size and biomass was significantly greater $(\mathrm{p}<0.0001)$ at $C r-S g$ sites $\mathrm{SL}=20.6 \mathrm{~cm}$ $( \pm 0.89 \mathrm{~cm})$, biomass $=0.28 \mathrm{~kg}( \pm 0.31 \mathrm{~kg})$ than $M g-S g$ sites $\mathrm{SL}=13.9 \mathrm{~cm}( \pm 0.56 \mathrm{~cm})$, biomass $=0.08 \mathrm{~kg}( \pm 0.11 \mathrm{~kg})$. Grunt movements resulted in a net transfer of $0.05 \mathrm{~kg}$ $( \pm 0.07 \mathrm{~kg})$ biomass from $\mathrm{Cr}$ to $\mathrm{Sg}$ while net transfer of $0.01 \mathrm{~kg}( \pm 0.03 \mathrm{~kg})$ biomass from $S g$ to $M g$ was observed. Overall, grunts contributed a net transfer of prey biomass from $\mathrm{Cr}$ to $S g(0.0005 \mathrm{~kg}, \pm 0.0007 \mathrm{~kg})$ and was demonstrated by each species except for H. aurolineatum (Figure 8b). H. sciurus was the only grunt species exhibiting a net transfer of prey biomass, $0.00002 \mathrm{~kg}( \pm 0.0001 \mathrm{~kg})$, from $M g$ to $S g$. Grunts accounted for $1.6 \%$ of prey biomass movement at $\mathrm{Cr}-\mathrm{Sg}$ sites and $0.8 \%$ of prey biomass movement at $\mathrm{Mg}$-Sg sites.

In terms of biomass, crabs, echinoderms, other crustacea, polychaetes, and shrimp were the most common prey items in grunt stomach contents. Crabs and echinoderms were the principal prey items at $C r-S g$ sites, while shrimp, other crustacea, and molluscs were primary items at $M g$-Sg sites (Figure 9b). Most prey items exhibited net transfer from $\mathrm{Cr}$ to $\mathrm{Sg}$ except echinoderms, seagrass, and other crustacea. Crabs, algae, molluscs, and shrimp exhibited net transfer of biomass from $S g$ to $M g$ while seagrass, other crustacea, polychaetes, and fish exhibited net transfer from $M g$ to $S g$. Echinoderms were not a prey item for grunts at $\mathrm{Mg}-\mathrm{Sg}$. Despite relatively high echinoderm biomass at $\mathrm{Cr}-\mathrm{Sg}$ (Figure 9b), 


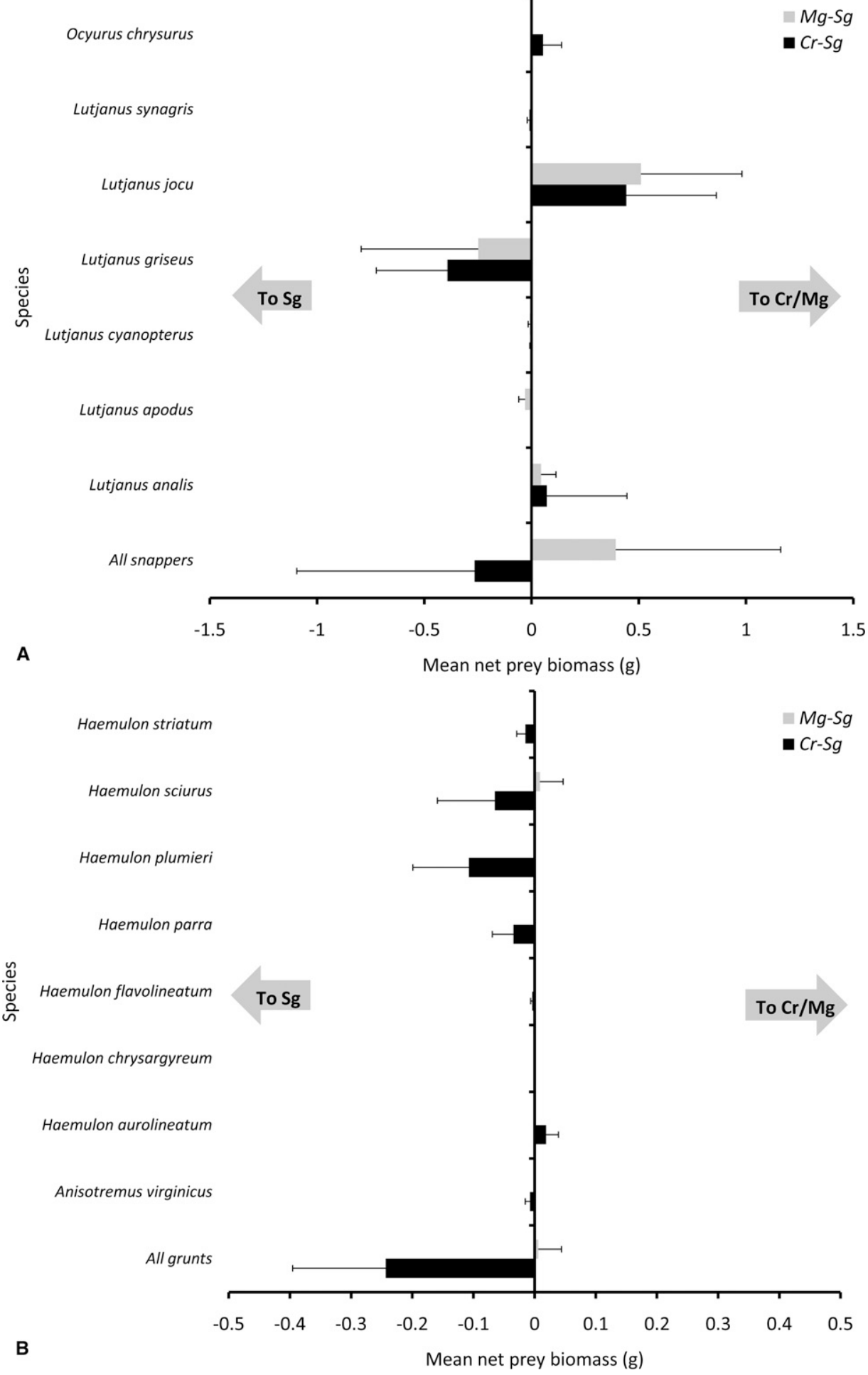

FIG. 8. Mean net flow of consumed prey biomass for: (a) snappers and (b) grunts. Negative values indicate movement into $S g$, positive values indicate movement into $\mathrm{Cr}$ or $\mathrm{Mg}$. 


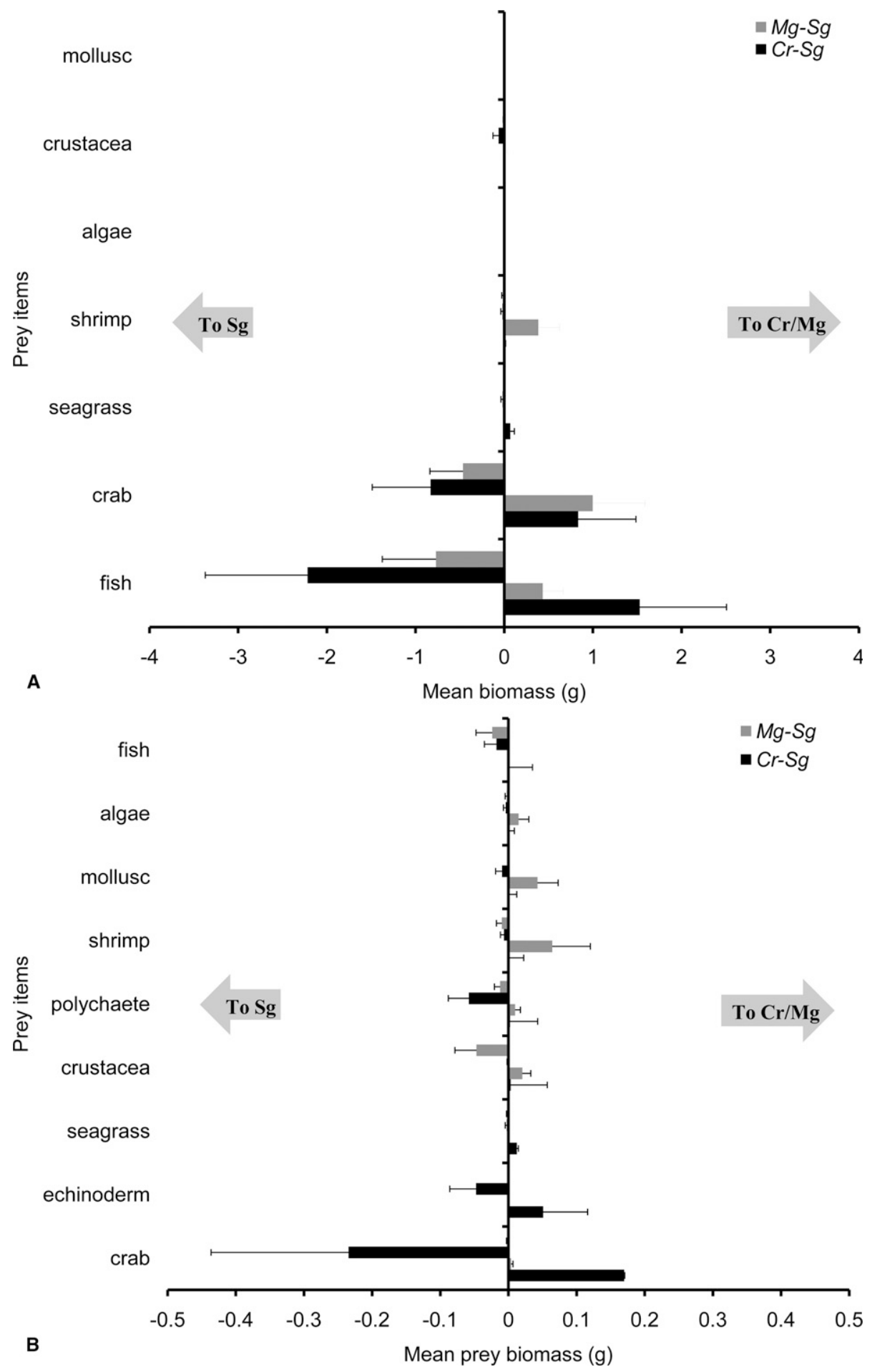

FIG. 9. (a) Snapper mean prey item biomass ( $\pm 1 S E$ ) flow at $C r-S g$ and $M g$ - $S g$ boundaries. (b) Grunt mean prey item biomass ( $\pm 1 \mathrm{SE}$ ) flow at $\mathrm{Cr}-\mathrm{Sg}$ and $\mathrm{Mg}$-Sg boundaries. Negative values indicate movement into $S g$, positive values indicate movement into $\mathrm{Cr}$ or $\mathrm{Mg}$. 
TABLE 4. Frequency of occurrence of prey items in snapper and grunt stomach contents at $\mathrm{Cr}-\mathrm{Sg}$ and $\mathrm{Mg}-\mathrm{Sg}$ boundaries. Prey items include al-algae, cr-crab, oc-other crustaceans, ec-echinoderms, fi-fish, mo-molluscs, po-polychaetes, se-seagrass, sh-shrimp.

\begin{tabular}{|c|c|c|c|c|c|c|c|c|c|c|}
\hline & $\mathrm{N}$ & al & $\mathrm{cr}$ & $\mathrm{oc}$ & ec & fi & mo & po & se & sh \\
\hline \multicolumn{11}{|l|}{$\mathrm{Cr}-\mathrm{Sg}$} \\
\hline All snappers & 21 & 4.76 & 33.33 & 14.29 & & 57.14 & 4.76 & & 19.05 & 14.29 \\
\hline L. analis & 3 & & 133.33 & & & 33.33 & & & 66.67 & 33.33 \\
\hline L. griseus & 8 & 12.50 & 12.50 & 12.50 & & 62.50 & & & 12.50 & \\
\hline L. jocu & 5 & & 18.89 & 0.02 & & 79.59 & & & 1.48 & \\
\hline All grunts & 46 & 8.51 & 46.81 & 51.06 & 19.15 & 8.51 & 29.79 & 27.66 & 6.38 & 21.28 \\
\hline H. plumieri & 17 & 5.56 & 38.89 & 33.33 & 22.22 & 11.11 & 27.78 & 22.22 & & 16.67 \\
\hline H. sciurus & 17 & 17.65 & 70.59 & 64.71 & 23.53 & 5.88 & 35.29 & 35.29 & 11.76 & 23.53 \\
\hline H. flavolineatum & 3 & & & 33.33 & & & 66.67 & & & \\
\hline H. aurolineatum & 3 & & 33.33 & 66.67 & & 33.33 & & & & \\
\hline \multicolumn{11}{|l|}{ Mg-Sg } \\
\hline All snappers & 46 & 2.17 & 39.13 & 4.35 & & 43.48 & & & & 17.39 \\
\hline L. griseus & 27 & 3.70 & 25.93 & 3.70 & & 44.44 & & & & 22.22 \\
\hline L. jocu & 13 & & 76.92 & & & 46.15 & & & & 15.38 \\
\hline All grunts $H$. sciurus & 24 & 8.33 & 37.50 & 66.67 & & 4.17 & 50.00 & 25.00 & 4.17 & 29.17 \\
\hline
\end{tabular}

frequency of occurrence was low and was considered less important for grunt prey items (Table 4). Other crustaceans and crabs and were the prevalent dietary source for grunts at $\mathrm{Cr}-\mathrm{Sg}$. Crabs were most important for bluestriped grunts (H. sciurus) with lesser importance attributed to other crustaceans, while other grunt species exhibited similar frequencies between crabs and other crustaceans. Crabs were less prominent in grunt stomach contents at $M g$-Sg while other crustaceans and molluscs were more significant dietary items compared to grunt stomach contents at $\mathrm{Cr}-\mathrm{Sg}$.

Prey types transported by fish across coral reef ecosystem boundaries. - A total of 458 fish stomachs were examined $(\mathrm{Cr}-\mathrm{Sg} \mathrm{n}=266, \mathrm{Mg}$ $S g \mathrm{n}=192)$. Twenty percent of all stomachs were empty at each boundary. Crabs, algae, echinoderms, and fish exhibited the greatest prey biomass at $M g$-Sg sites representing $60 \%$ of total biomass. For most prey types, biomass exported from $M g$ was greater than biomass imported into $M g$ at night (Figure 10); only polychaetes and seagrass plant material exhibited net gains for biomass. Algae, echinoderm and fish biomass composed 70\% of total prey biomass at $\mathrm{Cr}$-Sg. Nearly all prey items exhibited net gains of biomass at $\mathrm{Cr}$-Sg; other crustacea, mollusc, and shrimp biomass exhibited net losses.
Crabs and molluscs ranked first or second in frequency of occurrence among prey movement at $\mathrm{Cr}-\mathrm{Sg}$ and $\mathrm{Mg}-\mathrm{Sg}$ (Table 5). Crabs were the most frequently observed prey at $M g$ and were observed in over 50\% of the fish captured leaving Mg. Crabs were the most frequent prey item in fish leaving $\mathrm{Cr}$ while molluscs were observed slightly more frequently than crabs in fish entering $\mathrm{Cr}$. Fish and algae ranked third at $\mathrm{Mg}-\mathrm{Sg}$ while algae were more frequently observed than fish at $\mathrm{Cr}-\mathrm{Sg}$. Fish ranked fourth and third for prey importance at $\mathrm{Cr}-\mathrm{Sg}$ and $\mathrm{Mg}-\mathrm{Sg}$, respectively.

\section{DISCUSSION}

Many tropical fish species conduct migrations of varying spatial and temporal scales (daily, ontogenetic) across a mosaic of habitat types within a seascape, yet little is known of the regular crepuscular and nocturnal patterns of movement that take place in fish communities across habitat boundaries. This paper measures several components of functional connectivity, especially as it pertains to energy transfer through the flux of living biomass across the seascape and the type and quantity of associated biomass in the form of ingested prey. Most trophic flow studies have focused on individual taxa, thus this study represents a 


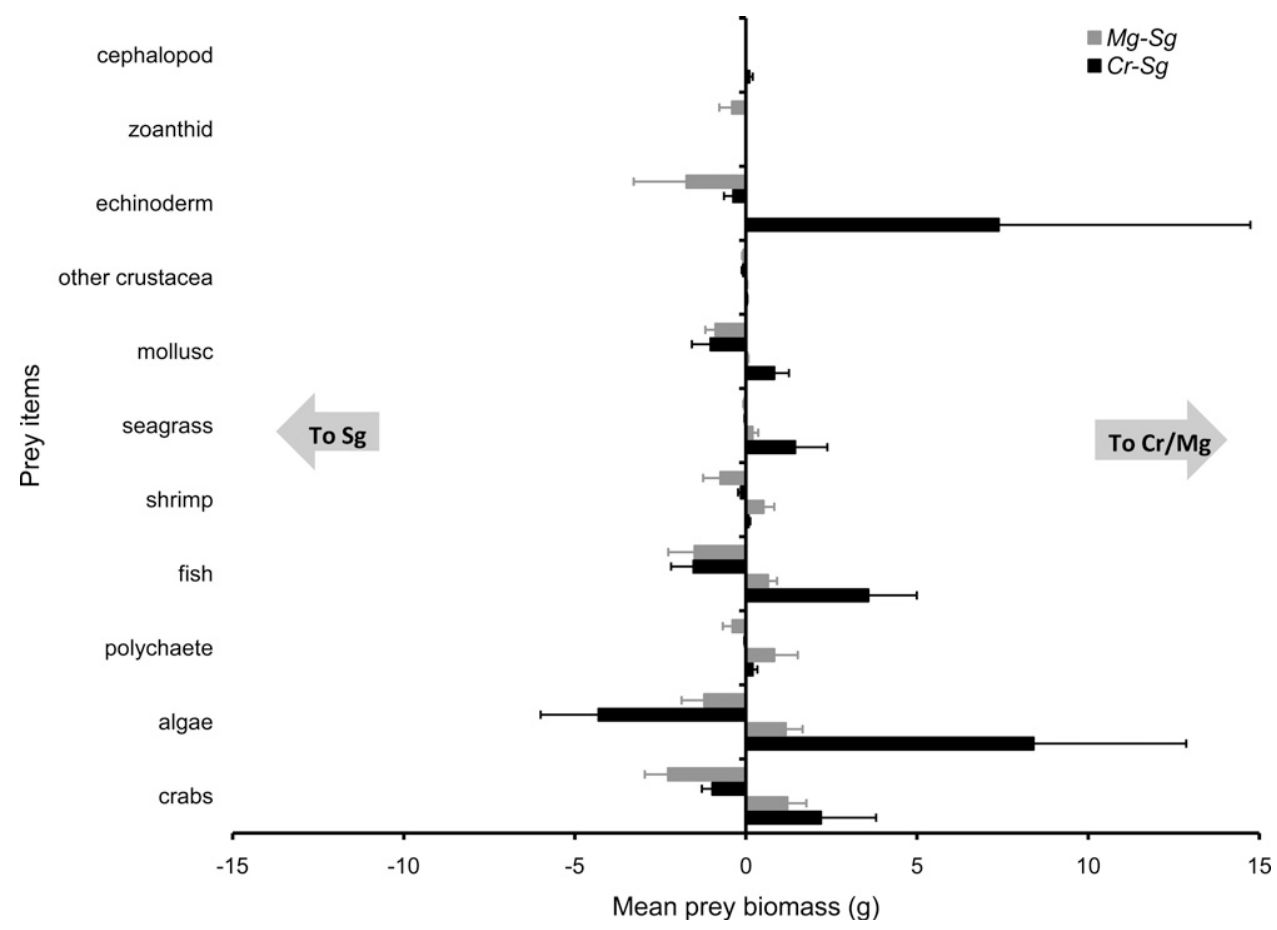

FIG. 10. Mean prey item biomass ( $\pm 1 \mathrm{SE}$ ) for all fishes captured at $\mathrm{Cr}-\mathrm{Sg}$ and $\mathrm{Mg}$-Sg boundaries. Negative values indicate movement into $S g$, positive values indicate movement into $\mathrm{Cr}$ or $\mathrm{Mg}$.)

unique community-wide perspective of fish movement, their prey and associated biomass in a coral reef ecosystem. Trophic flow information is vital to understanding ecosystem function (Christensen and Pauly 2004) and is considered the key method that determines (a) ecosystem state and (b) the connectivity of biomass between ecological groups or trophic levels (Monaco and Ulanowicz 1997; Gascuel et al. 2008).

In the present study, we detected the movements and prey transport of 67 fish species representing four trophic groups. Our results support previous observations that many fish species use coral reefs and mangroves as refuge during the day and venture out to adjacent habitat types (seagrass, algal beds, unconsolidated sediments) to feed during low light levels (Ogden and Ehrlich, 1977; Birkeland, 1985; Parrish et., 1989). However, our results do not support that prey biomass flow into resting habitats are significantly greater than that leaving. Mean flow at $\mathrm{Cr}-\mathrm{Sg}$ habitats followed the pattern suggested by earlier trophic studies (Ogden and Erhlich 1977; Ogden and Zieman 1977; McFarland et al. 1979) with net flow of prey biomass greater for fish returning to resting habitats after nocturnal foraging, however, flow was not statistically significant which suggests that the net transfer of prey biomass between reef and seagrass is essentially zero. Whether this is an artifact of the sampling design and error associated with differential digestive rates needs to be further investigated. It is possible that there is a dependence on habitat quality, such as reef size or reef and seagrass benthic composition that may have influenced these patterns.

Mangroves have been considered feeding areas for fishes that reside on adjacent mud flats and seagrass beds (Sheaves and Molony 2000); however, Nagelkerken and van der Velde (2004a) claim that mangroves are less important for fish residing in adjacent habitats than for fish that reside in mangroves. This study indicated that mangrove habitats serve as a feeding area (or 
TABLE 5. Directional frequency of occurrence and rank (in parentheses) of prey items for all fish captured at $\mathrm{Cr}$ $S g$ and $M g$ - $S g$ boundaries. Prey items include al-algae, cr-crab, oc-other crustaceans, ec-echinoderms, fi-fish, momolluscs, po-polychaetes, se-seagrass, sh-shrimp.

\begin{tabular}{|c|c|c|c|c|}
\hline & $\mathrm{Sg}-\mathrm{Cr}$ & $\mathrm{Cr}-\mathrm{Sg}$ & $\mathrm{Sg}-\mathrm{Mg}$ & $\mathrm{Mg}-\mathrm{Sg}$ \\
\hline Total fish catch & 123 & 143 & 89 & 103 \\
\hline crab & $27.64(2)$ & $33.57(1)$ & $30.34(1)$ & $54.81(1)$ \\
\hline mollusc & $28.45(1)$ & $25.87(2)$ & $23.60(2)$ & $39.42(2)$ \\
\hline algae & $21.95(3)$ & $20.28(4)$ & $19.10(3)$ & $16.35(3)$ \\
\hline fish & $17.88(4)$ & $13.29(5)$ & $19.10(3)$ & $16.35(3)$ \\
\hline other crustacean & $17.88(4)$ & $23.08(3)$ & $14.61(5)$ & $15.38(5)$ \\
\hline shrimp & $6.50(8)$ & $13.29(5)$ & $12.36(6)$ & $12.50(6)$ \\
\hline seagrass & $7.32(7)$ & $4.20(9)$ & $3.37(8)$ & $8.65(7)$ \\
\hline polychaete & $7.32(6)$ & 9.09 (7) & $8.99(7)$ & $6.73(8)$ \\
\hline echinoderm & $4.88(9)$ & $6.99(8)$ & $0(9)$ & $3.85(9)$ \\
\hline
\end{tabular}

the habitats are frequently visited) for a wide range of multi-habitat fish species including sharks, jacks, rays, and snappers. Species level prey trophic flow may also be influenced by adult/juvenile migration patterns and diurnal feeding within the mangroves (Nagelkerken and van de Velde 2004b). Thus, the flow at mangroves is complex, where residents may feed within the mangroves and import prey biomass from adjacent seagrass habitats while other fishes extract biomass (Nagelkerken and van der Velde 2004a, b).

Using results from this study we estimate 47.6 individuals $/ \mathrm{km}(\mathrm{SD} \pm 36.4)$ migrating between coral reefs and adjacent seagrasses. This estimate includes 3.75 snappers $/ \mathrm{km}$ $(\mathrm{SD} \pm 7.2), 8.21$ grunts $/ \mathrm{km}(\mathrm{SD} \pm 12.8)$, and 7.8 pelagic/non-residents $/ \mathrm{km}(\mathrm{SD} \pm 13.1)$. Fish movement at the $\mathrm{Mg}$-Sg boundary yielded 29.8 individuals $/ \mathrm{km}(\mathrm{SD} \pm 18.2)$, which include 7.1 snappers $/ \mathrm{km}(\mathrm{SD} \pm 8.2)$, 3.7 grunts $/ \mathrm{km}(\mathrm{SD} \pm 7.2)$, and 3.4 pelagic/ non-resident individuals $/ \mathrm{km}(\mathrm{SD} \pm 5.6)$. These estimates are likely underestimates of the entire communities that reside in these habitats due to the selectivity of the sampling gear and further studies should target smaller species. Similarly, prey biomass is likely underestimated due to differential digestive rates, and the duration of net soak times. Therefore, our estimates of prey biomass flow exhibiting net transfer of 0.016 $\mathrm{kg} / \mathrm{km}$ from $\mathrm{Sg}$ to $\mathrm{Cr}$ and $0.006 \mathrm{~kg} / \mathrm{km}$ from $M g$ to $S g$ are likely underestimated, but combined with prey frequency of occur- rence provide insight into relative transfer of prey and their biomass. Prey item frequency of occurrence for the fish communities sampled highlight the importance of crabs, molluscs, and algae being transported among the habitats.

We observed net transfer of prey biomass from reef to seagrass for L. griseus, L. synagris, L. cyanopterus, and all but one grunt species. Our results primarily represent subadults and adults and thus do not include the many juveniles that are also likely to move across patch boundaries to forage at night. More intensive field work with smaller gillnet mesh size supplemented by acoustic tracking surveys and gut content analysis could be integrated to gain more direct evidence of species trophic flows across a broader size range. Acoustic surveys have shown differences between adult and juvenile migrations, where adults were more active on the resting reef and off-reef migrations were not as structured as that seen for juveniles (Tulevich and Recksiek 1994; Beets et al. 2003). In fact, Tulevich and Recksiek (1994) observed adult white grunts (H. plumieri) roaming around reef habitats during the day and did not move off the reef at night. At present, the question of migration timing is not well understood, and patterns could vary by species, by size, and by habitat arrangement (size, relief, etc). Manual acoustic tracking of individual $H$. sciurus and L. apodus in St. John (U.S. Virgin Islands) has shown several individuals exhibiting high site fidelity 
to a specific location on a coral reef during both day and night (S. Hitt and S.J. Pittman, unpublished data). While our results were observations collected over a shorter duration compared to acoustic surveys, results cannot address migration consistency. Most of the clear patterns have been observed with grunts, and may not be a common representation for reef and mangrove communities.

Many factors work synergistically to determine fish community structure within a given reef or mangrove site, such as the composition and spatial configuration of the seascape as a whole, as well as the withinhabitat structure of coral reefs, mangroves and seagrasses (Kendall et al. 2003; Pittman et al. 2004; Pittman et al. 2007a) and the bathymetric complexity of the surrounding area (Pittman et al. 2007b). These data represent a unique insight into multi-species and multi-habitat fish movement across patch boundaries within the region and the first estimates of trophic flow among the mosaic of habitat types. Additionally, fish movements can vary by taxa and life stage, therefore the results provided here need to be complemented with information on the abundance, movements and nutrient transport patterns of smaller fishes to provide a better estimate of community-wide energy flow.

The community structure at both $\mathrm{Cr}-\mathrm{Sg}$ and $M g-S g$ sites was strongly influenced by transient pelagic species, such as jacks, sharks, and rays. Their abundance was generally low, however their large size accounted for almost $50 \%$ of the total biomass. When transient species were excluded from estimates of trophic flow at $\mathrm{Cr}$-Sg sites, net gains of prey biomass declined by $63 \%$. Similarly, exclusion of non-residents at mangrove sites reduced net prey biomass flow by $75 \%$. Our results indicate that predation (top-down processes) on coral reefs was a significant process however our results indicate that coral reefs and mangroves are likely to function as both a sink and a source for nutrients transported by fishes. Predation by carnivorous jacks and sharks play an important role in structuring reef fish communities (Hixon 1991) and also for fish using mangroves (Ogden and Gladfelter 1983). The obvious significance of these results is the top-down process of predation, removal of biomass from habitats. Pelagic species in coral reef ecosystems can have home ranges from 1-5 km (Honebrink 2000; Cartamil et al. 2003), thus habitat connectivity could have a large spatial context connecting multiple habitat types through frequent transboundary movements.

Invertivores were the dominant trophic group among both habitat types. Jones et al. (1991) summarized that benthic invertebrate predators were the most speciose among all trophic groups within coal reef systems. In concordance with this observation, invertebrate prey biomass was the primary source of trophic flow at all habitat boundaries. Seagrass and mangrove habitats generally produce an abundant invertebrate fauna (Weinstein and Heck 1977; Wahbeh 1982) and we observed a wide diversity of invertebrate organisms among the stomach contents. Parrish et al. (1985) noted that nearly $75 \%$ of fish captured in the Northwest Hawaiian Islands consumed crustaceans, predominantly crabs and shrimp. In this study, crabs were dominant prey types in terms of total biomass and frequency of occurrence. Herbivores usually comprise the majority of fish biomass on reefs and are important for biomass turnover from primary producers to higher trophic levels (Ferreira et al. 2004). In this study, herbivores were considerably less abundant than invertivores and piscivores combined at both reef and mangrove sites. Zooplanktivores were rare at both reef and mangrove sites and this group is probably not efficiently sampled by gillnets due to their schooling behavior above reefs and smaller size.

Grunts and snappers were abundant in gillnets, and nocturnal migrations to seagrass beds are well documented (Pollard 1984; Nagelkerken et al. 2000). Snappers were significant transporters of prey material in and out of coral reefs and mangroves as both consumers and providers of energy. Grunts were less significant contributors, accounting for only $1-2 \%$ of total prey biomass. Overall snappers contributed a net loss of prey biomass at reef sites. L. jocu and 
L. griseus were the most abundant snappers and $L$. jocu contributed net gains of prey biomass into reefs while L. griseus yielded net loss of prey biomass. Starck and Davis (1966) report that juvenile and sub-adult gray snapper exhibit diurnal foraging into adjacent seagrass habitats. Additionally, diurnal feeding on the reef may also occur where grunts and snappers may opportunistically forage in sandy reef interstices (Tulevech and Recksiek 1994).

Frequency of occurrence results indicated that fish were the dominant prey type for snappers at coral reef habitats, while fish and crabs were equally important in snapper stomachs from the mangroves. Crabs, echinoderms, and other crustaceans were the most important prey items for grunts on coral reefs, while molluscs, shrimp, and other crustacea were most important for grunts in the mangroves. While this may indicate ontogenetic differences, $L$. jocu and L. griseus size was not significantly different between the two habitats. Thus, prey density-dependent factors probably influence snapper diet at both sites. Individuals of H. sciurus were significantly smaller in mangroves and prey items were significantly different at reefs versus mangroves, which suggests ontogenetic shifts in habitat and diet (See Clark et al. 2003). This pattern has also been observed in southwest Puerto Rico (Dennis 1992) and other regions of the Caribbean (Mumby 2004; Cocheret de la Moriniere et al. 2003).

Gillnets are highly selective to the size of fish they capture, but generally unselective to the suite of fishes captured (Hickford and Schiel 2008). Gillnet surveys have not been efficient at characterizing reef communities; however, they are effective at capturing transient pelagic species and migratory reef species (Hickford and Schiel 2008), which was the primary objective for this study. There is little information about size selectivity or capture efficiency in tropical coral reef ecosytems (Acosta and Appeldoorn 1995). Acosta and Appeldoorn (1995) compared capture efficiency between a variety of gillnet types and mesh sizes at reef and mangrove sites in the same study area. Resulting finfish catch (excluding sharks and rays) using gillnets with similar mesh size $(7.6 \mathrm{~cm}$ stretched mesh, compared to our $5 \mathrm{~cm}$ ) but lower sample size, yielded similar catch at reef sites in terms of biomass $(2.8 \mathrm{~kg} / \mathrm{net})$ compared with the results presented here $(2.9 \mathrm{~kg} / \mathrm{net})$. However, their observed biomass at mangrove sites was lower $(1.1 \mathrm{~kg} /$ net $)$ compared to this study $(1.8 \mathrm{~kg} / \mathrm{net})$.

Gillnets are inefficient sampling tools for estimating fish density and size distribution, while other methods such as visual surveys can underestimate pelagic and cryptic species while also underestimating size distribution. For example, during this study mean fish size (FL) at reef and mangrove habitats was 27.8 and $26.5 \mathrm{~cm}$, respectively. Visual survey data collected from 2000-2006, yielded mean fish size (FL) less than $10 \mathrm{~cm}$ for both reef and mangrove habitats (Biogeography Branch [http://ccma. nos.noaa.gov/about/biogeography], unpublished data.). As such, the selectivity of the gear employed here is not representative of the community at large, but may be sufficient to comprehensively estimate subadult and adult movements in the ecosystem. Gillnet selectivity precluded us from making any estimates of fish movement and energy transport for fishes generally less than $10 \mathrm{~cm}$. Smaller fishes on reefs (such as grunts) are typically more abundant than larger fishes and have been shown to provide beneficial nutrients to benthic invertebrates on their reef schooling sites (Meyer and Schulz 1985). Additionally, the survey methods did not adequately sample zooplanktivores which are generally abundant in coral reef ecosystems.

Coral reef ecosystems are generally oligotrophic, thus the energy provided by fishes could be a significant source of nutrient enrichment for coral reefs. The transfer of energy between habitats may enhance other pathways of energy flow. For example, secondary production may be stimulated by migrating organisms (Ogden and Gladfelter 1983). Coral reefs are considered among the highest productive systems in the world due to their ability to efficiently recycle nutrients (Szmant 1983). Fishes that reside on reefs deposit waste products onto the reef and provide a substantial amount of organic material that is important for corals and other 
sessile invertebrates (Szmant 1983; Meyer and Schulz 1985). Top down processes, such as piscivory by large predators, may act to neutralize net gains of energy on reefs, but our study indicates that, while pelagic species do have an influence, the resident taxa import more than what is extracted.

\section{CONCULSIONS}

In this study, we examined movements and diets of a multispecies assemblage that provide insight into energy flow through the ecosystem. We observed that energy flow at night was multi-directional at both $\mathrm{Cr}-\mathrm{S} g$ and $\mathrm{Mg}$ - $\mathrm{Sg}$ sites where foraging activity among adjacent habitat types was high. Additionally, we infer that pelagic species play a considerable role in the flow of energy at both habitats and may connect habitats at scales of $\mathrm{kms}$. Snappers and grunts combined accounted for approximately $7 \%$ of prey biomass transfer at $\mathrm{Cr}-\mathrm{Sg}$ and $15 \%$ at $M g-S g$. We suggest that future energy flow research be conducted in conjuction with tracking data to further strengthen the understanding of connectivity in the region and provide support for resource management where connections are strongest. Furthermore, the broader scale patterning of the seascape surrounding the patch boundaries sampled in this study may explain some of the between site variability in abundance, diversity and biomass of fish thus adding a significant source of unquantified variability (Pittman et al. 2007b; Grober-Dunsmore et al. 2009). Future studies are needed that link fish movement behavior, trophic ecology and landscape ecology to comprehensively quantify the patterns of trophic connectivity across tropical marine seascapes.

Acknowledgements.-Funding for this project was provided by NOAAs Center for Sponsored Coastal Ocean Research. Additional support was provided by NOAAs Coral Reef Conservation Program and the University of the Virgin Islands. Sincere thanks to M. Prada and K. Foley for assisting with logistics to support the fieldwork and to all of R. Appeldoorn's staff for putting up with the variety of smells in the lab. Gracious thanks to K. Buja, T. Gill, M. Kendall, M. Nelson, and J. Waddell who contributed significantly to the fieldwork.

\section{Literature Cited}

Alheit, J. 1981. Feeding interactions between coral reef fishes and zoobenthos. In Proc. $4^{\text {th }}$ Int. Coral Reef Symp. ed. E. D. Gomez et al., 545-552, Manila.

Birkeland, C. 1985. Ecological interactions between tropical coastal ecosystems. UNEP Regional Seas Reports and Studies No. 73.

Bray, R. N., A. C. Miller, and G. G. Geese. 1981. The fish connection: A trophic link between planktonic and rocky reef communities. Science 214:204-205.

Cartamil, D. P., J. J. Vaudo, C. G. Lowe, B. M. Wetherbee, and K. N. Holland. 2003. Diel movement patterns of the Hawaiian stingray, Dasyatis lata: implications for ecological interactions between sympatric elasmobranch species. Mar. Biol. 142:841-847.

Clark, R., M. E. Monaco, R. S. Appeldoorn, and B. Roque. 2005. Fish habitat utilization in a Puerto Rico coral reef ecosystem. Proc. 56 $6^{\text {th }}$ Gulf Carib. Fish. Inst. 467-485.

Cocheret dela Morinière E., B. J. A. Pollux, I. Nagelkerken, and G. van der Velde. 2002.Post-settlement life cycle migration patterns and habitat preference of coral reef fish that use seagrass and mangrove habitats as nurserie. Est. Coast. Shelf Sci. 55:309-321.

Cocheret de la Moriniere, E., B. J. A. Pollux, I. Nagelkerken, and G. Van der Velde. 2003. Diet shifts of Caribbean grunts (Haemulidae) and snappers (Lutjanidae) and the relation with nursery-tocoral reef migrations. Est. Coast. Shelf Sci. 57:1-11.

Cortes, E. 1997. A critical rewiew of methods studying fish feeding based on analysis of stomach contents: application to elasmobranch fishes. Can. J. Fish. Aquat. Sci. 54:726-738.

Dahlgren, C. P., and D. B. Eggleston. 2000. Ecological processes underlying ontogenetic habitat shifts in a coral reef fish. Ecology 81:2227-2240.

Dennis, G. D. 1992. Resource utilization by members of a guild of benthic feeding coral reef fish. $\mathrm{PhD}$ Dissertation. University of Puerto Rico, Mayaguez. $224 \mathrm{pp}$.

Dorenbosch, M., M., G. G. Grol, M. J. A. Christiansen, I. Nagelkerken, and G. van der Velde. 2005. IndoPacific seagrass beds and mangroves contribute to fish density and diversity on adjacent coral reefs. Mar. Ecol. Prog. Ser. 302:63-76.

Dulvy, N. K., R. P. Freckleton, and N. V. C. Polunin. 2004. Coral reef cascades and the indirect effects of predator removal by exploitation. Ecol. Lett. 7:410-416.

Ferreira, C., E. L., S. R. Floeter, J. L. Gasparini, B. P. Ferreira, and J. C. Joyeux. 2004. Trophic structure patterns of Brazilian reef fishes: a latitudinal comparison. J. Biogeogr. 31:1093-1106.

Gascuel, D., L. Morissette, M. L. D. Palomares, and V. Christensen. 2008. Trophic flow kinetics in marine ecosystems: Toward a theoretical approach to ecosystem functioning. Ecol. Model. 217:33-47. 
Grober-Dunsmore, R, S. J. Pittman, C. Caldow, M. A. Kendall, and T. Fraser. 2009. A landscape ecology approach for the study of ecological connectivity across tropical marine seascapes. In Ecological Connectivity Among Tropical Coastal Ecosystems, ed. I. Nagelkerken, 493-530. Springer, Netherlands.

Grol, M. G. G., M. Dorenbosch, E. M. G. Kokkelmans, and I. Nagelkerken. 2008. Mangroves and seagrass beds do not enhance growth of early juveniles of a coral reef fish. Mar. Ecol. Prog. Ser. 366:137-146.

Hall, D. J., E. E. Werner, J. F. Gilliam, G. G. Mittelbach, D. Howard, C. G. Doner, J. A. Dickerman, and A. J. Stewart. 1979. Diel foraging behavior and prey selection in the golden shiner (Notemigonus crysoleucas). J. Fish. Res. Board Can. 36 (9):1029-1039.

Helfman, G. S., J. L. Meyer, and W. N. McFarland. 1982. The ontogeny of twilight migration patterns in grunts (Pisces:Haemulidae). Anim. Behav. 30: 317-326.

Hickford, M. J. H., and D. R. Schiel. 2008. Experimental gill-netting of reef fish: Species-specific responses modify capture probability across mesh sizes. J. Exp. Mar. Biol. Ecol. 358:163-169.

Hixon, M. A. 1991. Predation as a process structuring coral reef fish communities. In The Ecology of Fishes on Coral Reefs. ed. P.F. Sale, 475-508. Academic Press, Inc., San Diego, CA.

Honebrink, R. R. 2000. A review of the biology of the family Carangidae, with emphasis on species found in Hawaiin waters. Division of Aquatic Resources, Dept. of Land \& Natural Resources, State of Hawaii. DAR Technical Report 20-01.

Jones, G. P., D. J. Ferrell, and P. F. Sale. 1991. Fish predation and its impact on the invertebrates of coral reefs and adjacent sediments. In The Ecology of Fishes on Coral Reefs, ed. P.F. Sale, 156-179. Academic Press, Inc., San Diego, CA.

Kendall, M. S., C. R. Kruer, K., R. Buja, J. D. Christensen, M. Finkbeiner, R. Warner, and M. E. Monaco. 2002. Methods used to map the benthic habitats of Puerto Rico and the US Virgin Islands. NOAA Tech. Mem. 152. Silver Spring, MD.

Kendall, M. S., J. D. Christensen, and Z. Hillis-Starr. 2003. Multi-scale data used to analyze the spatial distribution of French grunts, Haemulon flavolineatum, relative to hard and soft bottom in a benthic landscape. Environ. Biol. Fish. 66:19-26.

Kramer, D. L., and M. R. Chapman. 1999. Implications of fish home range size and relocation for marine reserve function. Environ. Biol. Fish. 55:65-79.

Kopp, D., Y. Bouchon-Navaro, M. Louis, and C. Bouchon. 2007. Diel differences in the seagrass fish assemblages of a Caribbean island in relation to adjacent habitat types. Aquat. Bot. 87:31-37.

Kulbicki, M., Y. M. Bozec, P. Labrosse, Y. Letourneur, G. M. Tham, and L. Wantiez. 2005. Diet composition of carnivorous fishes from coral reef lagoons of New Caledonia. Aquat. Living Resour. 18:231-250.

Meyer J. L., and E. T. Schultz. 1985. Migrating haemulid fishes as a source of nutrients and organic matter on coral reefs. Limnol. Oceanogr. 30(1):146-156.
Meyer, J. L., E. T. Schultz, and G. S. Helfman. 1983. Fish schools: An asset to corals. Science 220(4601): 1047-1049.

Monaco, M. E., and R. E. Ulanowicz. 1997. Comparative ecosystem trophic structure of three U.S. midAtlantic estuaries. Mar. Ecol. Prog. Ser. 161:239-254.

Monaco, M. E., A. Friedlander, S. D. Hile, S. J. Pittman, and R. H. Boulon. 2009. The coupling of St. John, US Virgin Islands marine protected areas based on reef fish habitat affinities and movements across management boundaries. Proc. $11^{\text {th }}$ Int. Coral Reef. Symp. Ft. Lauderdale, FL.

Mumby, P. J., A. J. Edwards, J. E. Arias-Gonzalez, K. C. Lindeman, P. G. Blackwell, A. Gall, M. I. Gorczynska, A. R. Harborne, C. L. Pescod, H. Renken, C. C. C. Wabnitz, and G. Llewellyn. 2004. Mangroves enhance the biomass of coral reef fish communities in the Caribbean. Nature 427:533-536.

Murray, S. N., R. F. Ambrose, J. A. Bohnsack, L. W. Botsford, M. H. Carr, G. E. Davis, P. K. Dayton, D. Gotshall, D. R. Gunderson, M. A. Hixon, J. Lubchenco, M. Mangel, A. MacCall, D. A. McArdle, J. C. Ogden, J. Roughgarden, R. M. Starr, M. J. Tegner, and M. M. Yoklavich. 1999. No-take reserve networks: protection for fishery populations and marine ecosystems. Fisheries 24(11):11-25.

Nagelkerken, I., M. Dorenbosch, W. Verberk, E. C. de la Moriniere, and G. van der Velde. 2000. Importance of shallow-water biotopes of a Caribbean bay for juvenile coral reef fishes: Patterns in biotope association, community structure and spatial distribution. Mar. Ecol. Prog. Ser. 202:175-192.

Nagelkerken, I., and G. van der Velde. 2004a. Are Caribbean mangroves important feeding grounds for juvenile reef fish from adjacent seagrass beds? Mar. Ecol. Prog. Ser. 274:143-151.

Nagelkerken, I., and G. van der Velde. 2004b. Relative importance of interlinked mangroves and seagrass beds as feeding habitats for juvenile reef fish on a Caribbean island. Mar. Ecol. Prog. Ser. 274:153-159.

Ogden, J. C., and P. R. Ehrlich. 1977. The behaviour of heterotypic resting schools of juvenile grunts (Pomadasyidae). Mar. Biol. 42:273-280.

Ogden, J. C., and E. H. Gladfelter.1983. Coral Reefs, Seagrass Beds, and Mangroves: Their Interaction in the Coastal Zones of the Caribbean. UNESCO Reports in Marine Science 23, 133 pp.

Parrish, J. D. 1989. Fish communities of interacting shallow-water habitats in tropical oceanic regions. Mar. Ecol. Prog. Ser. 58:143-160.

Parrish, J. D., M. W. Callahan, and J. E. Norris. 1985. Fish trophic relationships that structure reef communities. Proc. $5^{\text {th }}$ Int. Coral Reef Congr. 4:73-78.

Pittman, S. J., C. A. McAlpine, and K. M. Pittman. 2004. Linking fish and prawns to their environment: a hierarchical landscape approach. Mar. Ecol. Prog. Ser. 283:233-254.

Pittman, S. J., J. D. Christensen, C. Caldow, C. Menza, and M. E. Monaco. 2007a. Predictive mapping of fish species richness across shallow-water seascapes in the Caribbean. Ecol. Model. 204:9-21. 
Pittman, S. J., C. Caldow, S. D. Hile, and M. E. Monaco. 2007b. Using seascape types to explain the spatial patterns of fish in the mangroves of SW Puerto Rico. Mar. Ecol. Prog. Ser. 348:273-284.

Polis, G. A., W. B. Anderson, and R. D. Holt. 1997. Toward an integration of landscape and food web ecology: The dynamics of spatially subsidized food webs. Ann. Ecol. Syst. 28:289-316.

Pollard, D. A. 1984. A review of ecological studies on seagrass-fish communities, with particular reference to recent studies in Australia. Aquatic Botany 18:3-42.

Polunin, N. V. C., and C. M Roberts. 1993. Greater biomass and value of target coral-reef fishes in two small Caribbean marine reserves. Mar. Ecol. Prog. Ser. 100:167-176.

Randall, J. E. 1967. Food habits of reef fishes of the West Indies. Stud. Trop. Ocean. 5:665-847.

Rooker J. R., and G. D. Dennis. 1991. Diel, lunar and seasonal changes in a mangrove fish assemblage off southwestern Puerto Rico. Bull. Mar. Sci. 49: 684-698.

Sale, P. F. 2004. Connectivity, recruitment variation, and the structure of reef fish communities. Integr. Comp. Biol. 44:390-399.

SAS Institute. 2006. SAS/STAT ${ }^{\circ}$ Software. SAS Institute, Inc. Cary, NC. USA.
Sheaves, M. 2005. Nature and consequences of biological connectivity in mangrove systems. Mar. Ecol. Prog. Ser. 302:293-305.

Sheaves M., and B. Molony. 2000. Short-circuit in the mangrovefood chain. Mar. Ecol. Prog. Ser. 199:97-109.

Szmant-Froelich, A. 1983. Functional aspects of nutrient cycling on coral reefs. In The Ecology of Deep and Shallow Coral Reefs, ed, M. L. Reaka, 133-139. NOAA Undersea Research Program, Silver Spring, MD.

Unsworth, R. K. F., E. Wylie, D. J. Smith, and J. J. Bell. 2007. Diel trophic structuring of seagrass bed fish assemblages in the Wakatobi Marine National Park, Indonesia. Est. Coast. Shelf Sci. 72:81-88.

Unsworth, R. K. F., P. S. DeLeon, S. L. Garrard, J. Jompa, D. J. Smith, and J. J. Bell. 2008. High connectivity of Indo-Pacific seagrass fish assemblages with mangrove and coral reef habitats. Mar. Eco. Prog. Ser. 353:213-224.

Wahbeh, M. I. 1982. Distribution, biomass, biometry and some associated fauna of the seagrass community in the Jordan Gulf of Aqaba. Proc. 4th Int. Coral Reef Symp. 2:453-459.

Weinstein, M. P., and K. L. Heck. 1979. Ichthyofauna of seagrass meadows along the Caribbean coast of Panama and in the gulf of Mexico: composition, structure and community ecology. Mar. Biol. 50: 97-107. 